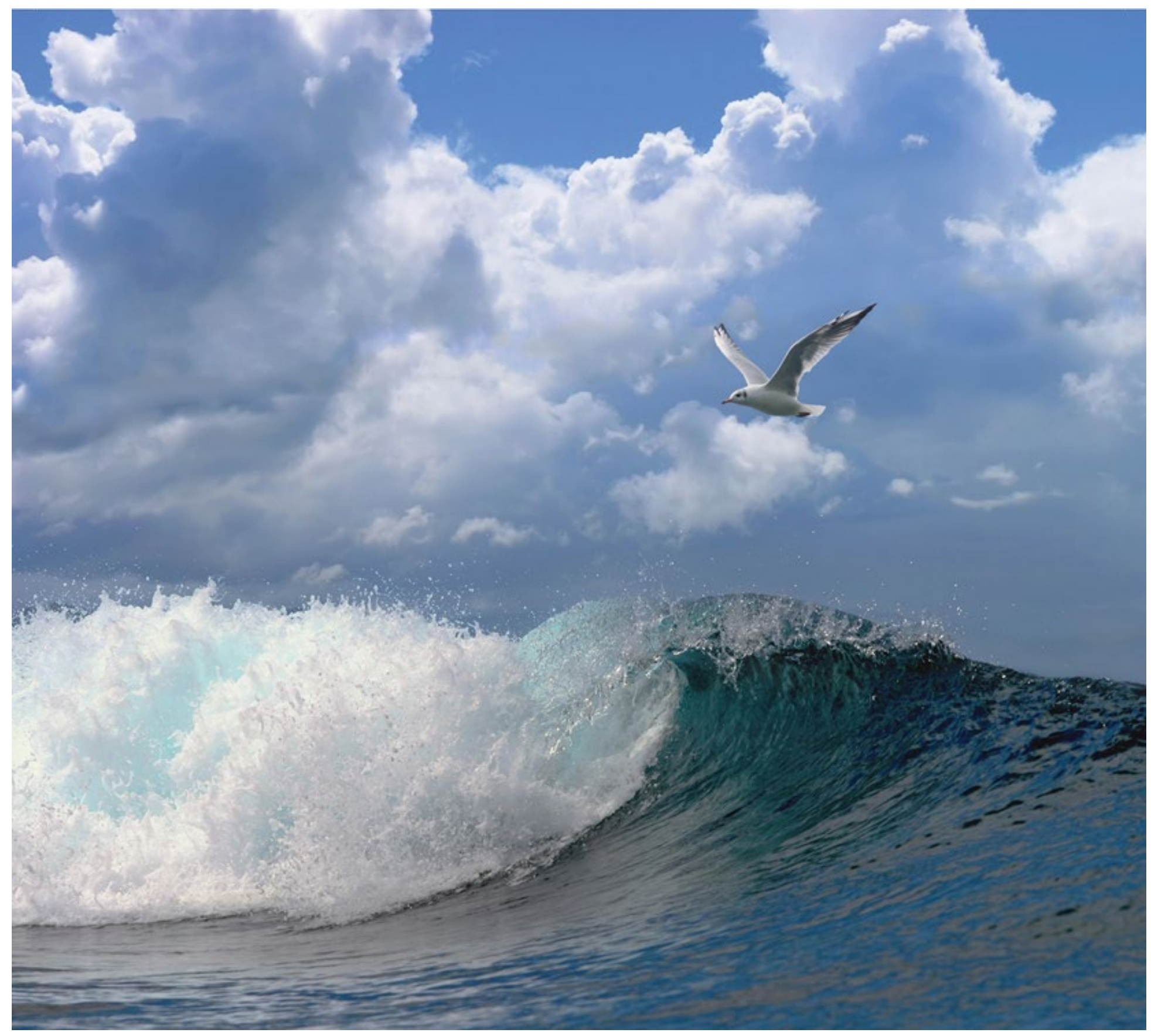

\title{
Assessing the stability and mobilisation of crab-pot-strings anchored with Bruce anchors under different marine conditions
}




\section{Assessing the stability and mobilisation of crab-pot-strings anchored with Bruce anchors under different marine conditions}

With information of catchment of brown crab (Cancer pagurus), European lobster (Homarus gammarus) and other species

Authors: M.J.C Rozemeijer ${ }^{1}$, C. Chun ${ }^{1}$, R. Cramer ${ }^{2}$, A. Korving ${ }^{3}$, C. Meeldijk ${ }^{1}$

\footnotetext{
1: Wageningen Marine Research

2: Cramer Noordwijk Beheer B.V.

3: Noordzee Charters
}

This research project was carried out by Wageningen Marine Research and subsidized by the ministry of Agriculture, Nature and Food Quality for the purposes of Policy Support Research Theme BO-43 Duurzame voedselvoorziening \& -productieketens \& Natuur Project no. BO-43-119.01-028 Add Ankermobilisatie krabben).

Wageningen Marine Research

IJmuiden, December 2021

CONFIDENTIAL No

Wageningen Marine Research report C107/21 
Keywords: Anchors, offshore windfarm, passive fisheries, multi-use, risk reduction, risk evaluation, Cancer pagurus, Homarus gammarus, Necora puber

Client: $\quad$ Ministerie van LNV

Attn.: Erik Tichelaar

Bezuidenhoutseweg 73

2594 AC, Den Haag

f.s.tichelaar@minlnv.nl

BO-43-119.01-028

This report can be downloaded for free from https://doi.org/10.18174/560823

Wageningen Marine Research provides no printed copies of reports

Wageningen Marine Research is ISO 9001:2015 certified.

\section{(C) Wageningen Marine Research}

Wageningen Marine Research, an institute within the legal entity Stichting Wageningen Research (a foundation under Dutch private law) represented by

Drs.ir. M.T. van Manen, Director Operations

KvK nr. 09098104

WMR BTW nr. NL 8113.83.696.B16.

Code BIC/SWIFT address: RABONL2U

IBAN code: NL 73 RABO 0373599285
Wageningen Marine Research accepts no liability for consequential damage, nor for damage resulting from applications of the results of work or other data obtained from Wageningen Marine Research. Client indemnifies Wageningen Marine Research from claims of third parties in connection with this application.

All rights reserved. No part of this publication may be reproduced and / or published, photocopied or used in any other way without the written permission of the publisher or author.

A_4_3_2 V31 (2021) 


\section{Contents}

$\begin{array}{lr}\text { Summary } & 5\end{array}$

$\begin{array}{llr}1 & \text { Introduction } & 7\end{array}$

$\begin{array}{lll}1.1 & \text { Background } & 7\end{array}$

$\begin{array}{lll}1.2 & \text { Knowledge need and research objective } & 7\end{array}$

$\begin{array}{lll}\text { 1.2.1 } & \text { Risk evaluation sessions } & 7\end{array}$

$\begin{array}{lll}1.2 .2 & \text { Practical tests } & 7\end{array}$

1.2.3 Bruce anchors $\quad 9$

1.3 Research questions $\quad 9$

1.3.1 Demarcation 9

$\begin{array}{ll}1.3 .2 & \text { Reading Guide } \\ \end{array}$

$2 \quad$ Materials and Methods $\quad 12$

$2.1 \quad$ Expeditions and strings $\quad 12$

2.1.1 Planning and weather 12

2.1.2 Location and measurement 12

$\begin{array}{ll}2.1 .3 & \text { String-setup }\end{array}$

2.2 Catchment testing of crab and lobster 13

$\begin{array}{lll}2.2 .1 & \text { Catchment and catch per unit effort } & 13\end{array}$

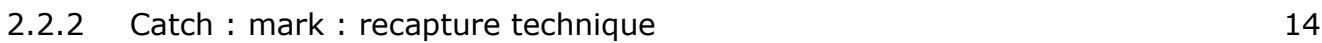

$\begin{array}{lll}2.2 .3 & \text { Statistical methods } & 14\end{array}$

$3 \quad$ Results $r$

$\begin{array}{lll}3.1 & \text { Expeditions and conditions } & 15\end{array}$

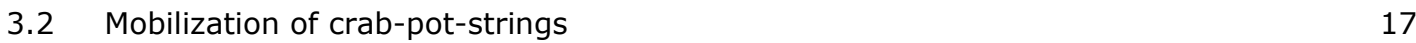

3.3 Species, catchment \& saturation curves 17

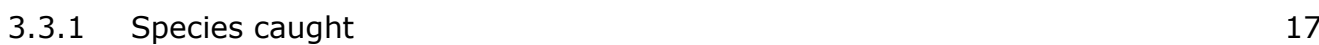

3.3.2 Catchment in time 18

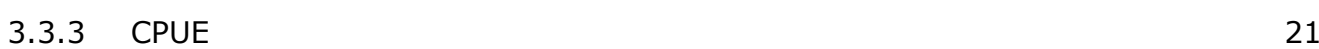

3.3.4 Mark and recapture $\quad 22$

4 Discussion $\quad 23$

$\begin{array}{lll}4.1 & \text { Weather summer } 2021 & 23\end{array}$

$\begin{array}{lll}4.2 & \text { Mobilization of crab-pot-strings } & 24\end{array}$

$\begin{array}{lll}4.3 & \text { Catchment of brown crabs, lobster and bycatch } & 24\end{array}$

$\begin{array}{lll}4.3 .1 & \text { Wrecks } & 24\end{array}$

$\begin{array}{lll}\text { 4.3.2 Brown crab } & 25\end{array}$

$\begin{array}{lll}4.3 .3 & \text { Velvet swimming crab } & 27\end{array}$

$\begin{array}{lll}4.3 .4 & \text { Other bycatch } & 27\end{array}$

$5 \quad$ Conclusions and recommendations $r$

5.1 Chance of mobilising strings with anchoring 28

5.2 Catching brown crab, velvet swimming crab and other animals 28

5.2.1 Saturation vs soak time $\quad 28$

$\begin{array}{ll}5.2 .2 \text { CPUE } & 29\end{array}$

5.2.3 Pot position $\quad 29$

5.2.4 Other bycatch $\quad 29$

5.2.5 Mark and recapture $\quad 29$

5.2.6 Overall conclusion on catching crab and lobster 29 
5.3 Recommendations

5.3.1 Chance of mobilising Bruce anchors

5.3.2 Crab fisheries

References

Justification

34

Annex 1

Figures

35 


\section{Summary}

This study is a sequel of the project BO-43-119.01-012 KD-2021-018_Alternatieve ankers in windparken op zee in which adapted anchors were investigated for suitability of passive fisheries with crab-pot-strings in Offshore Wind farms (OWFs) in general and Prinses Amalia Offshore Windpark (PAWP) in particular.

\section{Introduction}

Fishing, working and manoeuvring within OWFs is very different from fishing outside OWFs in the North Sea. There are additional conditions and high requirements to allow other activities in OWFs. In risk evaluation sessions for passive fisheries with crab-pot-strings in PAWP with Eneco (as a part of the project Win-Wind), it was determined that crab-pot-strings must be provided with dahns (buoys with flagsticks, Figure 1) in accordance with legal provisions. When using chain bunches to fixate crabpot-strings with dahns to the seabed, they become mobile in high water levels, currents and winds, running the risk of getting caught in the infield-electricity-cables and damaging them. Due to this risk, Eneco withheld permission for the use of strings with dahns, anchored by chain-bunches in PAWP).

In this project we elaborate on the work method statement for passive fisheries with crab-pot-strings in PAWP. The risk (=chance $*$ damage: $\mathrm{R}=\mathrm{c} * \mathrm{D}$ ) (Equation 1 ) of using anchors in PAWP had to be assessed to continue development of experimental passive fisheries in PAWP. We studied the chance variable of anchoring crab-pot-strings with Bruce anchors for the risk-equation for infield electricity cables. In addition, we studied the suitability of the set up to catch brown crab (Cancer pagurus) and European lobster (Homarus gammarus) and bycatch.

\section{The chance variable of the Risk assessment of anchoring with Bruce anchors}

To determine the risk, this study estimated the chance of mobilization of crab-pot-strings anchored with regular Bruce anchors (the chance variable in equation 1). It was a very windy summer in 2021 with several periods with Bft 7 and also maxima to $18 \mathrm{~m} / \mathrm{s}$ (=8 BFt). In this sense the chance variable was tested under severe conditions that do not often occur during summer.

Out of $120(10 * 6 * 2)$ tests, only 1 Bruce anchor has moved. It turned out to be tangled in its own rope. That side of the crab-pot-string was moved $40-50 \mathrm{~m}$, the other side was not. Concluding: the chance that a crab-pot-string is mobilized at wind force $7 \mathrm{Bft}$ and lower range of $8 \mathrm{Bft}$ is very low (independent of the number of Bruce anchors per side). According to the risk evaluation systematics of Eneco, Change = 1 (May never occur) (Rozemeijer et al., 2020).

Given the fact that two anchors on the same side have a higher chance to become entangled and also the risks on board with extra wires and thereby personal being pulled overboard, it is not advisable to work with double anchors at each side.

\section{Suitability of the set up to catch brown crab, velvet swimming crab and other animals} It appeared possible to catch brown crab and velvet swimming crab in larger amounts at the three wrecks that were used as location. European lobster was hardly caught at the three wrecks. Other species of interest could be Sepia which was caught in very low amounts.

\section{Saturation vs soak time}

Both brown crab and velvet swimming crab reached a saturation in pot loading after $\sim 7$ days. These results are comparable to other studies. It suggests that the period between the hauling of strings can be on the higher side ( $\geq 4$ days), to optimise the catchment of tagged animals. However, wind and wave conditions in the summer 2021 required revision of the original planning after every expedition. In addition, earlier experiences showed that wind conditions may deviate from the general patterns (alike other authors). It seems better to plan trips with 4-7 days interspace and to be flexible with those dates which allows to adjust to circumstances and take the opportunities offered. 


\section{Catch per unit effort}

With a Catch per unit effort (CPUE) of 0.3 to 1 brown crab per pot per day the results of present study are on the lower side as compared to other studies. Causes can be the amount of suitable substrate: a wreck on soft sediments. The average density of brown crabs on the soft substrate of the Dutch Continental Shell is low. Given the fact that the optimal habitat of hard substrate is limited (only the wrecks), and the Key West is almost gone, a low CPUE seems in line with local circumstances. Other auteurs did their research at renowned crab grounds with ample hard substrate. Also the extent and shape of the bait scent plume could be of significance in the lower CPUE as compared to others.

Velvet swimming crab CPUEs were more in line with CPUE results reported by other auteurs.

Pot position in the string

The pot position in the string was of significance. The most likely cause is that the characteristics of the tidal currents have directed most of the bait scent plume towards the northern pots. In PAWP crab-pot-strings will be parallel to the currents (Rozemeijer et al., 2020) and on the northern site of the monopiles: a non-favourable position. To improve long term bait scent a plume tub gurnard will be added in new experiments.

\section{Bycatch}

Bycatch (other than velvet swimming crab) was of minor importance in present study. Also European lobsters had a minor contribution to the total catch. Registration of total bycatch will continue in the PAWP experiment adding also the measurement of the carapace width of velvet swimming crab (using $6.8 \mathrm{~cm}$ as MLS, (Minimum Landing Seize)).

\section{Mark Recapture}

A $3.4 \%$ of the tagged brown crab was recaught. The amount of tagged animals in the crab-pots increased steadily with time from 1 day to 8 days soak time. After 10 days soak time a sudden drop was observed and no tagged brown crab was recaptured. There is no explanation for this phenomenon. The $3.4 \%$ is in line with another author who did a similar study. It is expected these data are sufficient to determine population seize in a future study.

\section{Overall conclusion on catching crab and lobster}

It is possible to catch brown crab and other species with the tested set-up. The use of anchors does not hamper catchment. Tagged animals were also recaptured proving the validity of the approach (Catch : Mark : Recapture). Recommendations are made for additional knowledge acquirement (e.g. test mobility of strings under more severe conditions). 


\section{Introduction}

\subsection{Background}

Offshore Wind farms (OWFs) in the North Sea are necessary to achieve the Dutch government's climate and energy targets. At the same time, fishermen see their access to fishing grounds reduced by these OWFs, leading to discontent within the fishing community. In order to bring these opposing interests closer together, the government aims to combine multiple user functions within OWFs. Passive fishing and aquaculture are increasingly mentioned as potential activities that may be combined with OWFs.

To investigate the possibilities for multi-use of OWFs, The 'Win-Wind' consortium started a research and test pilot of passive fisheries on European lobster (Homarus gammarus) and brown crab (Cancer pagurus) fishing in OWF Prinses Amalia WindPark (PAWP) in the North Sea (financed by TKI Wind op Zee). This project includes research into the ecological aspects of European lobster and brown crab fishing, market opportunities for this type of food products, and reducing operational risks when fishing in an OWF.

Fishing, working and manoeuvring within OWFs is very different from performing these type of activities outside OWFs in the North Sea. There are additional conditions and high requirements that apply in OWFs to allow other activities. Knowledge is also required about new target species, innovative or adapted fishing methods and knowledge of the risks that can occur when, for example, fixating crab-pot-strings on the sea bed in an OWF. Reducing operational risks for fishing in OWFs has a high priority from a safety and liability perspective for the Dutch government.

\subsection{Knowledge need and research objective}

\subsubsection{Risk evaluation sessions}

In risk evaluation sessions with Eneco (Rozemeijer et al., 2020), it was determined that the crab-potstrings must be provided with dahns (buoys with flagsticks) with the desired marking (flags, etc.) in accordance with legal provisions (EU 2005, MinEZLI, 2021, Rozemeijer et al., 2020). These sessions also showed that Eneco preferred chain bunches instead of anchors (Figure 1). Chain bunches are preferred to prevent possible damage of an anchor hooking into the infield-electricity-cables connecting the turbines (Figure 2A). In addition, chains are preferred on rocky seabed, typical crab habitats. Also chain bunches work more convenient on board (less entanglement with ship parts etc.).

\subsubsection{Practical tests}

For a risk assessment and to describe on the behaviour of cage-strings equipped with dahn and chain clusters, earlier tests were carried out outside PAWP (Korving et al., 2021, Rozemeijer et al., 2022a). Here it was shown that strings with dahns and chain clusters are quickly mobilized by Maximum water level compared to Nieuw Amsterdam Peil (NAP) (from 1.21 m onwards, Figure 3, Korving et al., 2021, Rozemeijer et al., 2022a,b,c) (highly correlated with (tidal) current ). Strings with bladders (round fender) simply remain in place until at least $1.84 \mathrm{~m}$ maximum water level compared to NAP (Korving et al., 2021, Rozemeijer et al., 2022a).

Strings with dahns, anchored by chain bunches, which become mobile in high water levels and high currents (Figure 2), run the risk of getting caught in the electricity infield cables and damaging them. Due to this risk, Eneco withheld permission for the use of strings with dahns, anchored by chain bunches in PAWP. The fishermen also prefer not to work with dahns because they are difficult to handle with risk of personal harm. The use of fenders instead of dahns could have been a solution. However, it is impossible to get an exemption for their use because of European legislation. 


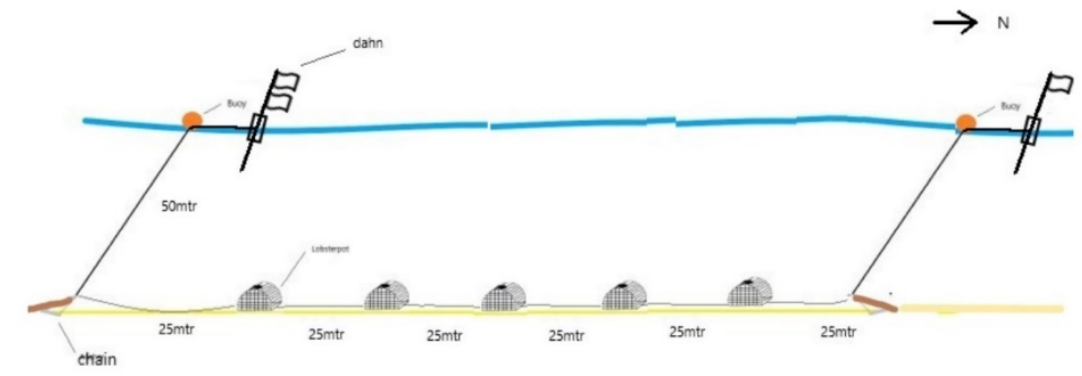

Figure $1 \mathrm{Crab}$-pot-strings with five cages and two chain-clusters. Next to the buoy a dahn is attached with flag(s) and radar reflector. The double flag means the most southern buoy of the string. A single flag signs the most northern buoy. In this set up mutual distance between the pots is $25 \mathrm{~m}$. Currently this distance is topic of discussion and can be up to $60 \mathrm{~m}$, depending on local water depths.

Figure 2
A: The infield-electricity-cable with a diameter of 146 mm, with an alike construction
as the PAWP infield-electricity-cable: from the outside in: 1. Raffia cover (very thin);
2. Thin bitumen layer; 3. Galvanized steel wires; 4. Bitumen coating; 5. Three
electricity cables with a similar structure.
B: The default Bruce anchor and two adapted variants with several bars, from the
end point of a fluke to prevent the adapted Bruce anchor from hooking into the
cable.




\subsubsection{Bruce anchors}

Since it is impossible to get an exemption for the use of fenders the research focused on anchors as an option for fixating the strings sturdy to their position. The Bruce anchor was chosen because it has been an internationally renowned anchor for at least 40 years (Figure 2B, Box 1). It is also often used by Dutch fishermen especially for rigging. Here it performs well under the dynamic circumstances the North Sea offers.

\section{Adapted Bruce anchors}

In a first attempt, Bruce anchors were adapted such that the hooking of the anchor in infieldelectricity-cables was prevented. A major accompanying disadvantage was that the adaptations also prevented the digging in of the adapted Bruce anchor thereby annihilating its usability (Rozemeijer et al., 2021).

\section{Un-adapted Bruce anchors}

The next option is to equip crab-pot-strings with dahns and original, un-adapted Bruce anchors. During the risk evaluation session of 14-01-2021, it was concluded that there were serious doubts about the anchoring behaviour, both grip in the bottom and hooking into and damaging an infieldelectricity-cable, normally $1 \mathrm{~m}$ deep buried in the seabed but at times exposed. Also in an evaluation of the preliminary results of Rozemeijer et al. (2021), it was decided to assess estimates on the risk of anchors hooking in Infield cables. Risk is chance * damage $\left(R=c^{*} D\right)$ (Equation 1$)$.

To test the aspect of chance, $\mathrm{c}$ in equation 1, it was decided by the Ministry of Agriculture, Nature and Food Security (Ministry of LNV) to test the potential mobilisation of strings with Bruce anchors in an actual field situation under differing natural circumstances (alike Korving et al., 2021, Rozemeijer et al., 2022a) but now with Bruce anchors instead of chain-bunches). Since this is a new set-up for Dutch circumstances (Tonk \& Rozemeijer, 2021), the catchment of brown crab, European lobsters and bycatch will be tested as well.

For Ministry of LNV this knowledge was also of utmost relevance as fundamental knowledge to define the boundary conditions for multi-use and applicability of Bruce anchors in all OWFs.

\subsection{Research questions}

Research questions are:

1. Are the strings with a set-up of five crab pots mobilised under summer weather ${ }^{1}$ and current conditions when they are anchored with one or two Bruce anchors on each end (so replace the chain clusters in Figure 1, with one or two anchors)?

2. Is it still possible to catch brown crab and European lobster with this novel set-up?

A set-up with one or two anchors was chosen, as inspired by common practice in rigging. The Dutch seabed is soft, sandy and mobile and under unpredictable circumstances (but often North-western storm) the seabed is mobilised and the sandy floor losses its coherence. Then there is a risk a rig can get lost. However, once two Bruce anchors are placed on either side, the riggs will not be mobilised under these extreme conditions (that seldom occur in summertime).

\subsubsection{Demarcation}

Only one type of anchor was tested. More modern anchors are available as well like the Rocna anchor with more grip while having lighter weight. However, these anchors are so expensive and for regular small-scale fisheries, these are out of range for a viable business model. In addition they usually have

1 A string length of 5 crab pots was chosen in the WMS (Rozemeijer et al., 2020), of such length that the crab-pot-strings could be placed parallel to the currents and not crossing the next infield-electricity-cable and also leaving enough space for the CTVs to manoeuvre. The tests were done under summer conditions conform the agreements between the consortium Win-wind, Eneco, Ministry of LNV and Rijkswaterstaat. 
a sharp point and edges strengthening burial behaviour but posing more risk for damage to the infield-electricity-cable due to these sharp features.

The intention for the tests was to have a widespread in wind and tidal conditions and submergence periods of the strings. However, the conditions of the weather and sea state are unpredictable as such it is obligatory to follow that what is offered by circumstances. Luckily it was a stormy summer in 2021.

\subsubsection{Reading Guide}

According to a classical set-up, Materials and Methods are given in chapter 2, Results in chapter 3, Discussion in chapter 4, Conclusion and recommendations are given in chapter 5.

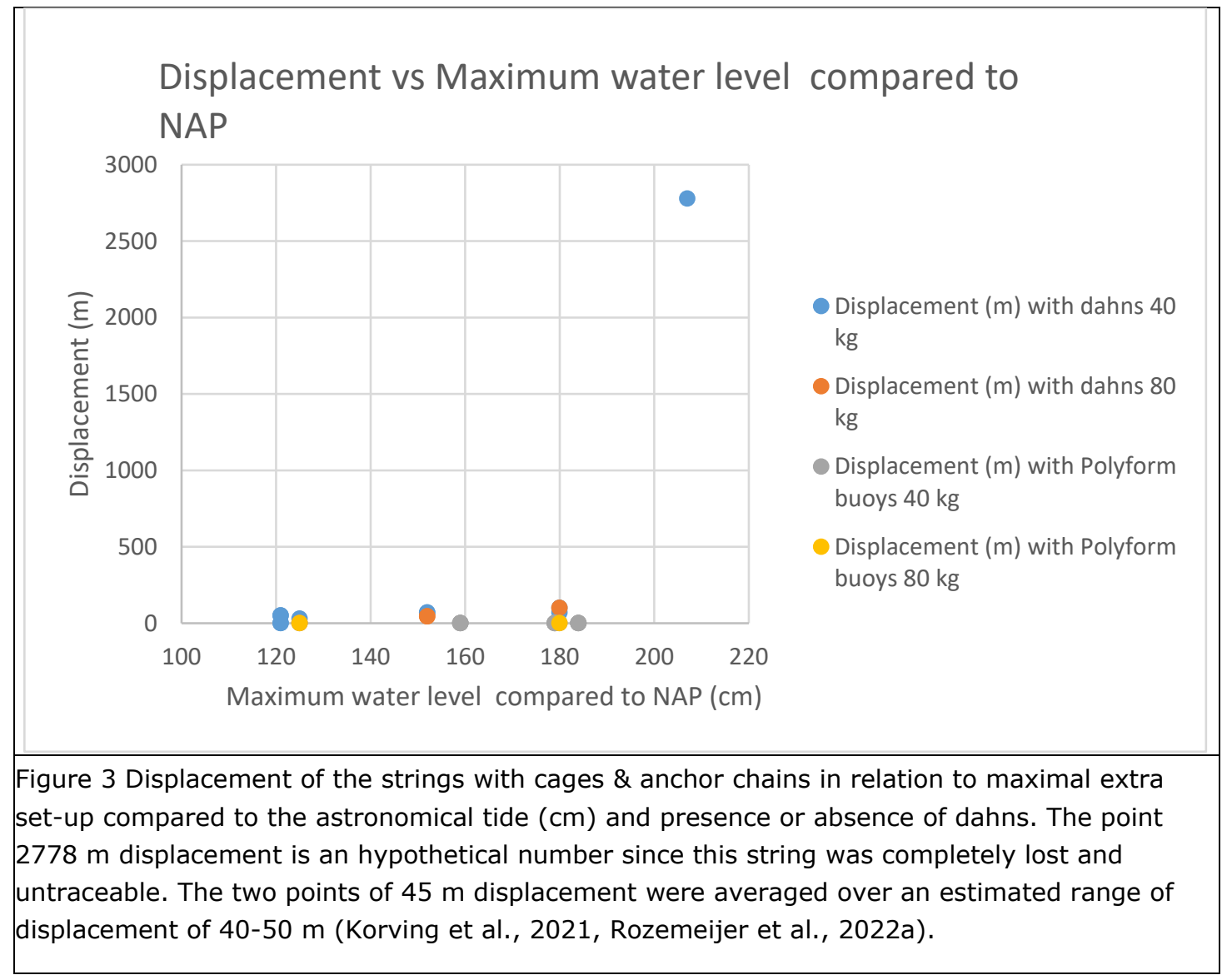


Box 1 Bruce or claw anchor from https://en.wikipedia.org/wiki/Anchor\#Bruce_or_claw_anchor ; https://www.petersmith.net.nz/boat-anchors/old-generation-anchors.php ; d.d. 29-10-2021.

The Bruce anchor was an evolutionary improvement in its day. It is most effective in larger sizes. This claw-shaped anchor was designed by Peter Bruce from the Isle of Man in the 1970s, UK patent filled in 1971. Bruce gained his early reputation from the production of large-scale commercial anchors for ships and fixed installations such as oil rigs. The anchor features a triple fluke configuration which forms a 'claw' shape. It was later scaled down for small boats, and copies of this very popular design abound. The Bruce and its copies, known generically as "claw type anchors", have been adopted on smaller boats (partly because they stow easily on a bow roller) but they are most effective in larger sizes. It enjoyed a good level of success, addressing many of the problems, mostly those pertaining to setting reliability, of the CQR and Danforth, then the only alternatives for small boats.

Claw anchors are quite popular on charter fleets as their percentage set on the first try in many bottom types is very high. They have the reputation of not breaking out with tide or wind changes, instead slowly turning in the bottom to align with the force.

Bruce anchors can have difficulty penetrating weedy bottoms and grass. The claw has three separate flukes, all fairly blunt, which do not cut and penetrate weed or grass very well. This also affects its setting performance in hard sand and clay. The configuration of the flukes tends to act as a trap for rocks and boulders, and other undersea obstacles. Bruce anchors do not perform particularly well in terms of holding power as compared to the newer designs like Rocna anchors. They are therefore inefficient, requiring a heavier anchor to achieve the same holding ability as newer designs. But proponents of the type tend to accept this trade-off. The anchor's benefits instead supposedly lie in setting reliability, and when compared to Danforth types it is true that claws generally perform better across a somewhat wider range of seabeds. And they are a lot cheaper than the newer designs. A $15 \mathrm{~kg}$ Bruce anchor costs € 90,-, a $20 \mathrm{~kg}$ Bruce anchor costs $\sim € 140$, whereas a $15 \mathrm{~kg}$ Rocna anchor costs $\sim € 500,-$. Given such price differences, the disadvantages of the Bruce anchor can easily be overcome by selecting a larger Bruce anchor, being slightly more expensive, instead of a lighter, modern design, more expensive anchor. 


\section{Materials and Methods}

The set-up was that six crab pot strings were placed at three wrecks. The positions were registered and at set times strings were lifted, positions registered again to determine displacement. The pots were emptied, baited and deployed. Location and approach were alike Korving et al. (2021, Rozemeijer et al., 2022a). The caught brown crab and European lobsters were tagged and released upstream for recapture. Bycatch was registered as well.

Data on water and weather were obtained from Rijkswaterstaat and where needed related to the displacement.

The catchment data were used for saturation versus soak time and catch per unit effort (CPUE) vs time determination. Catch : Mark : Recapture data on European lobsters and brown crab were obtained to test whether marked animals were recaught and also to evaluate if population estimates at the wrecks can be performed in a subsequent study.

\subsection{Expeditions and strings}

A total of 10 expeditions was planned. On expedition day 1 the strings were placed and expedition day 10 the strings were removed. The Perseverance ( $\mathrm{SCH} 61$ ) was used, departing from the harbour of Scheveningen.

\subsubsection{Planning and weather}

A planning was made with an even spread in periods of soak time (time between deployment and retrieval of pots) to establish a curve of numbers of brown crab caught versus soak time over the total range. Weather conditions (wave height, wind), however, were determining the final expeditionsdates. Workable conditions were defined at wind force 0-3 Bft, with a wave height of $1.0 \mathrm{~m}$ max.

\subsubsection{Location and measurement}

At the wrecks Adder, Houtrust and Key West (Figure 10, Figure 11, , Figure 12, Figure 13) each two strings were deployed: one westward and one eastward of the wreck. These wrecks were chosen because of their close proximity to Scheveningen. Circumstances in weather and hydrography are most likely alike PAWP (Caires \& Pathirana, 2019). Also the seabed dynamics are comparable (Smaal et al., 2017). Positions nearby wrecks were chosen to reduce the chance the strings would be damaged by beam trawling ships One of the strings was equipped with one Bruce anchor on each side, the other string was equipped with two Bruce anchors on each side. The positions eastward or westward of the wreck was switched when possible at a sea expedition. The strings are placed parallel to the prevailing current direction at 15 to 50 meters distance to the wrecks.

At each expedition day the displacement of the strings was determined. In addition the strings were hauled for a check on integrity of the string and to prevent to excessive accumulation of sediment that will prevent any mobilisation by currents or waves. A heavily sedimented string is not representative to crab pot fisheries where the strings are hauled on a regular basis.

\section{The wrecks}

Zr.Ms. Adder

The Zr.Ms. Adder (1875) was a Dutch naval ship, a ram monitor. It was a short and wide ship with a length of 59.56 meters and a width of 13.40 meters. Two steam engines on board provided the thrust of the two propellers of the ship. The Adder was an armoured ship and was therefore equipped with an armour, which was fourteen centimetres thick on the sides, and artillery. It sank on Wednesday evening 5 July 1882 between 21:00 and 21:30 in the North Sea off the coast of Scheveningen and lays at 18m depth (Figure 10, Figure 11). The Adder has the National Contact Number (NCN) 17 and 
is known to the Hydrographic Service under number 2053. Position 52.143089 N 4.160334 E, or $52^{\circ}$ $08.58 \mathrm{~N} 004^{\circ} 09.62 \mathrm{E}$.

\section{Houtrust}

The Houtrust wreck (Hydrographic Service-id: 2058; Rijkswaterstaat id: 1902) is an unidentified wreck. The first notice of the wreck was in 1949 (Ministry of Defence). It is a metal (steel or iron) ship but details are unknown. Seize $40 \times 6 \times 2 \mathrm{~m}$. It is suspected that it is a cargo ship (Figure 12). Position

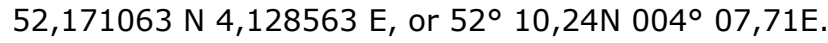

Key West

Key West is wooden Danish diesel motor vessel, fishing vessel type, sunk on June 30, 1986 after colliding with the Panamanian tanker Tonegawa. (Hydrographic Service-id: 2495, Figure 13). Depth ranges are 10 to $17 \mathrm{~m}$ depth, dimensions are $14 \times 14 \times 0.8$. Location $52,168137 \mathrm{~N} 4,149434 \mathrm{E}$, or $52^{\circ}$ $10,08 \mathrm{~N} 004^{\circ} 08,97 \mathrm{E}$. It was made predominantly of wood.

\subsubsection{String-setup}

The pots were set in strings. A string consists of:

- 2 buoys $A 1$ type

- 2 dahns

- $310 \mathrm{mtr}$ of rope

- $\quad 2$ or 4 Bruce anchors @ 10kgs each

- $\quad 5$ pots @ 28-32kgs

The strings consisted of 5 pots, with $40 \mathrm{~m}$ of cable in between (adapted from Figure 1). On the outer cages each a rope of $25 \mathrm{~m}$, then one or two Bruce anchors (weight: $10 \mathrm{~kg}$ each) and then a rope of 50 $m$ with a surface buoy (dahn). The strings were deployed parallel to the current (differently from the Waddenarea where currents are less strong, Tonk \& Rozemeijer, 2022). Next to the buoy a dahn is attached with flag(s) and radar reflector reducing the risk of accidental collisions.

Buoy lines were $14 \mathrm{~mm}$, potlines were $20 \mathrm{~mm}$. Each pot will be attached to the headrope with a spinner. All lines are split, except for the buoy/dahn connection and pots. These are connected with a spinner. There were no rotating parts which are subject to wear. This method has been used successfully for decades within this fishing method.

The dahns are made from Bamboo or GRP, with a foam float in the middle and a contra weight at the bottom, keeping the pole up. There are reflective tapes, a radar reflector and flashlights mounted on. A flag is on top. Two flags was the Southwest side of a string, 1 flag was the Northeast side.

All strings except for one had a set-up of three $28 \mathrm{~kg}$ crab-pots at positions 1, 3, 5 and two $32 \mathrm{~kg}$ crab-pots at positions 2 and 4. Only string with Id 1 had $528 \mathrm{~kg}$ crab-pots.

\subsection{Catchment testing of crab and lobster}

Two major questions were tested:

1. Can we determine catchment for the different set-ups?

2. Can we estimate CPUE?

3. Can tagged animals be recaught as a first step towards population estimates based om Catch : Mark : Recapture technique

\subsubsection{Catchment and catch per unit effort}

All animals caught were registered in relation to date, string, pot, location, time, for analysis. Brown crab and European lobster were sexed and measured for carapace width (CW) and length $(\mathrm{CL})$ respectively. Velvet swimming crab was sexed. All fish were measured for length. The CPUE was determined for each pot in relation to position and type of pot and also in relation to soak time. 


\subsubsection{Catch : mark : recapture technique}

\section{Tagging of animals}

All brown crab, European lobster and some velvet swimming crab were tagged with Hallprint T-bar tags: TBA Standard anchor T-bar tags for lobsters and double bar TBA LEVO tags for brown crab, all with a Hallprint VP-S Tagging Tool (for type TBA standard anchor T-Bar tags) (Hallprint Pty. Ltd, Holden Hill, South Australia). Previous studies (Smith et al. 2001; Moland et al. 2011, Skerrit, 2014) show that the T-bar tags are sufficiently durable to enable identification of recaptured animals after periods of up to several years, without appearing to affect survival or behaviour within the first year of tagging. Each tag has a unique five digit identification number, making it possible to construct accurate capture and movement records for each marked animal.

For lobster the tag was placed between carapace and first tail somite (tail harness segment). To that extend the lobster abdomen was bent carefully till the bare flesh of the tail muscle was visible. Then the tagging tool was directed tailwards (distal) at least one $\mathrm{cm}$ sideways from the middle track (preventing damage of critical organs) and inserted in the abdominal muscle. The tag was inserted, and only after making a quarter turn the tagging tool was retracted, enhancing the retention of the tag in the flesh.

For brown crab a $3 \mathrm{~mm} \varnothing$ incision was pierced with a dremel or awl in the posterior margin of the carapax at the line of division of the moult. The location was approximately $1 \mathrm{~cm}$ medial from the most lateral point. Both dremel and awl were blocked with a rubber cork after $5 \mathrm{~mm}$ to prevent excessive penetration and consecutive damage of the gills and body cavity. Next the tagging tool was inserted in the branchial cavity and the TBA LEVO tag was inserted.

Van Stralen \& Smeur (2008) cited that lobsters lose $10-20 \%$ of a slightly different type of tag (FloyTags). They measured $1.2 \%$ tag loss over one year field experiment (including molt and casual damage). Jurius \& Rozemeijer (unpublished data) measured spontaneous 0.166 tag loss/year/ind. for an individual non-moulting brown crab under laboratory conditions.

\subsubsection{Statistical methods}

A list of factors could have an impact on the catch number per pot: 1) Wreck; 2) east vs west side; 3) soaking time; 4) type of pot (crab vs lobster); 5) pot position. These factors were included in a GLM to test their effect on catch number. The catch per pot contains high proportion of zeros, therefore, the catch number was modelled as a negative binomial distribution. Models with the full set of variables and their interactions were tested using likelihood ratio test.

The statistical modelling was conducted under R 4.0.2 using package glmmTMB, the illustration of model effect was done using package effects.

Other variables were tested with ANOVA (XLSTAT). 


\section{Results}

The vessel used for the expeditions was the Perseverance ( $\mathrm{SCH}$ 61). The same vessel is programmed to be used for the tests in PAWP. Different boundary and preferred conditions for working are given in Table 1.

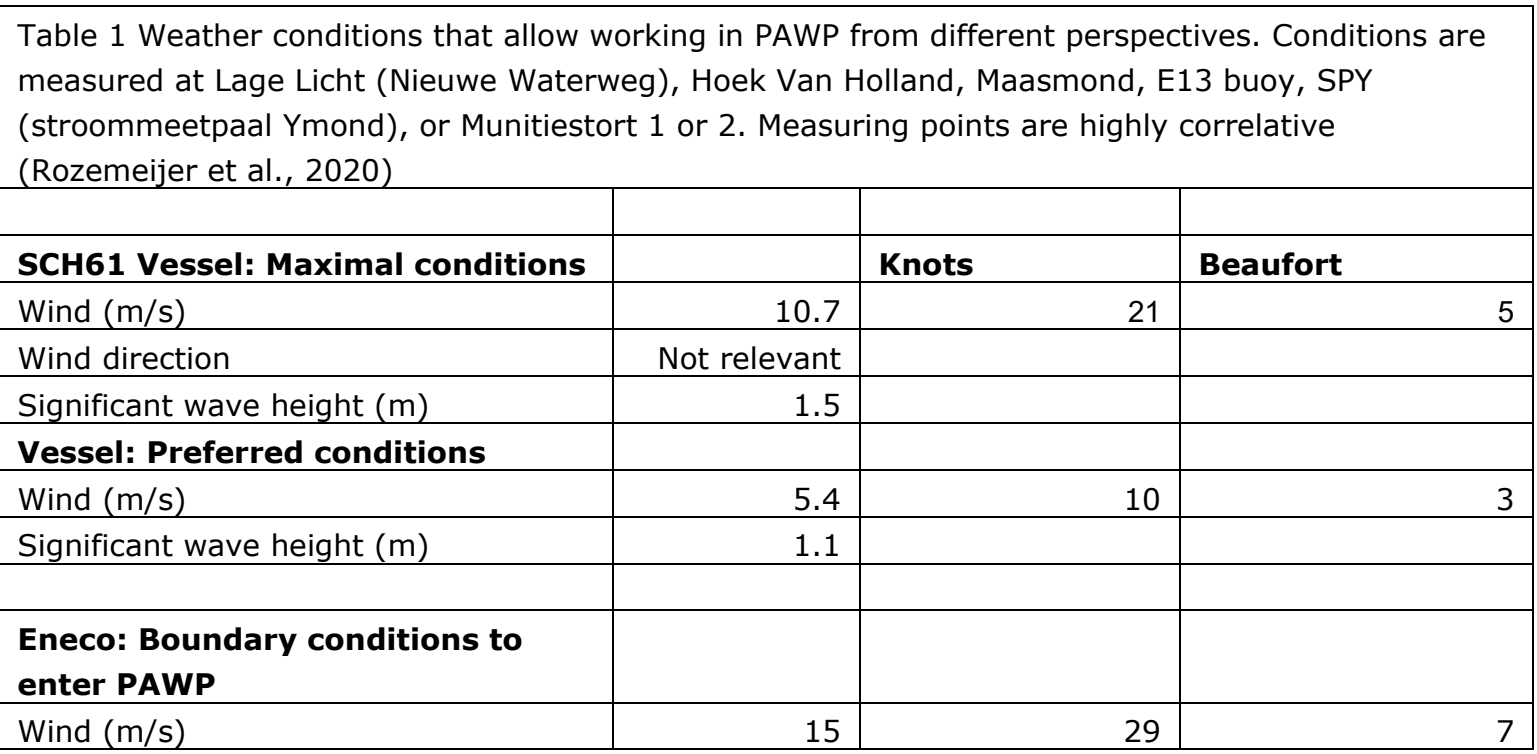

\subsection{Expeditions and conditions}

The expeditions were performed from 1-8-2021 (baiting and first deployment of the strings) to 18-092021 (final haul out, Table 2). The soak time (deployment duration) ranged from 1 day to maximally 10 days (average 5.33 days). Catchment saturation curves usually follow a Holling Type II functional response $^{2}$ (Spencer, 2011, Skerrit 2014, Tully et al., 2006). Expeditions were ideally planned curve to include a range of soak times (that differed in length) but weather conditions had to be followed resulting in the actual implementation.

Rijkswaterstaat data were obtained from Hoek van Holland and E13. The maximum water level ranged from 127 to $162 \mathrm{~cm}$ per period (average: $147 \mathrm{~cm}$, Table 2). The 10 min averaged wind force ranged from 5.4 to $12.6 \mathrm{~m} / \mathrm{s}$ (average: $9.9 \mathrm{~m} / \mathrm{s}, 5 \mathrm{Bft}$ ). The maximal wind force ranged from 7.4 to 18.0 ( 8 $\mathrm{Bft}$ ) at $222^{\circ}$ what is South-West on the compass rose. One period with $8 \mathrm{Bft}$ has occurred, three periods with $7 \mathrm{Bft}$, two periods with $6 \mathrm{Bft}$, two periods with $5 \mathrm{Bft}$ and one period with $4 \mathrm{Bft}$. The wind periods with 7 and $8 \mathrm{Bft}$ ranged from South-West $\left(222^{\circ}\right)$ to North-North-East $\left(22^{\circ}\right)$. The average E13 10 min averaged Wave height was $166 \mathrm{~cm}$ (with $298 \mathrm{~cm}$ as maximum and $57 \mathrm{~cm}$ as minimum). The average E13 maximal Wave height was $298 \mathrm{~cm}$ (with $528 \mathrm{~cm}$ as maximum and $102 \mathrm{~cm}$ as minimum). The average E13 10 min averaged Swell height was $44 \mathrm{~cm}$ (with $106 \mathrm{~cm}$ as maximum and $4 \mathrm{~cm}$ as minimum). The maximal extra set-up compared to the astronomical tide was calculated as a measure for currents. It was $27 \mathrm{~cm}$ on average and $61 \mathrm{~cm}$ maximally and $1 \mathrm{~cm}$ minimally.

\footnotetext{
2 the intake rate of a consumer as a function of food density
} 


\begin{tabular}{|c|c|c|c|c|c|c|c|c|c|c|c|}
\hline $\begin{array}{l}\text { Dates of } \\
\text { expeditions }\end{array}$ & Purpose & $\begin{array}{l}\text { Soak } \\
\text { time }\end{array}$ & \begin{tabular}{|l|} 
First \\
string \\
out of \\
the \\
water \\
\end{tabular} & $\begin{array}{l}\text { Water } \\
\text { level } \\
\text { Hoek van } \\
\text { Holland } \\
\end{array}$ & $\begin{array}{l}\text { Lage Licht } \\
\text { wind } \\
\text { force (10 } \\
\text { min } \\
\text { average) } \\
\end{array}$ & \begin{tabular}{|l|} 
Lage \\
Licht \\
Maximal \\
wind \\
force \\
\end{tabular} & $\begin{array}{l}\text { Lage Licht } \\
\text { Wind } \\
\text { direction } \\
\text { of maximal } \\
\text { wind force } \\
\end{array}$ & $\begin{array}{l}\text { E13 Wave } \\
\text { height (10 } \\
\text { min } \\
\text { average) }\end{array}$ & $\begin{array}{l}\text { E13 } \\
\text { maximum } \\
\text { Wave } \\
\text { height } \\
\end{array}$ & $\begin{array}{l}\text { E13 Swell } \\
(10 \mathrm{~min} \\
\text { average })\end{array}$ & $\begin{array}{l}\text { Maximal extra set- } \\
\text { up compared to } \\
\text { the astronomical } \\
\text { tide }\end{array}$ \\
\hline dd-mm-yyyy & & (days) & hh:mm & $\mathrm{cm}$ & $\mathrm{dm} / \mathrm{s}$ & $\mathrm{dm} / \mathrm{s}$ & degrees & $\mathrm{cm}$ & $\mathrm{cm}$ & $\mathrm{cm}$ & $\mathrm{cm}$ \\
\hline $1-08-21$ & Bait, deploy & & $9: 00$ & & & & & & & & \\
\hline $11-08-21$ & $\begin{array}{l}\text { Bait, measure, } \\
\text { tag }\end{array}$ & 10 & $8: 54$ & 153 & 123 & 180 & 222 & 298 & 505 & 45 & 57 \\
\hline $12-08-21$ & $\begin{array}{l}\text { Bait, measure, } \\
\text { tag }\end{array}$ & 1 & $8: 54$ & 137 & 58 & 79 & 231 & 57 & 116 & 4 & 9 \\
\hline $20-08-21$ & $\begin{array}{l}\text { Bait, measure, } \\
\text { tag }\end{array}$ & 8 & $8: 33$ & 156 & 145 & 168 & 312 & 280 & 528 & 73 & 61 \\
\hline $21-08-21$ & $\begin{array}{l}\text { Bait, measure, } \\
\text { tag }\end{array}$ & 1 & $8: 45$ & 127 & 54 & 74 & 222 & 91 & 158 & 106 & 13 \\
\hline $25-08-21$ & $\begin{array}{l}\text { Bait, measure, } \\
\text { tag }\end{array}$ & 4 & $8: 40$ & 156 & 126 & 145 & 28 & 191 & 340 & 18 & 18 \\
\hline $1-09-21$ & $\begin{array}{l}\text { Bait, measure, } \\
\text { tag }\end{array}$ & 7 & $9: 45$ & 160 & 126 & 157 & 354 & 247 & 446 & 81 & 35 \\
\hline $6-09-21$ & $\begin{array}{l}\text { Bait, measure, } \\
\text { tag }\end{array}$ & 5 & $8: 55$ & 118 & 105 & 115 & 23 & 137 & 236 & 27 & 1 \\
\hline $10-09-21$ & $\begin{array}{l}\text { Bait, measure, } \\
\text { tag }\end{array}$ & 4 & $8: 45$ & 152 & 62 & 82 & 232 & 61 & 102 & 8 & 17 \\
\hline $18-09-21$ & $\begin{array}{l}\text { Measure, tag, } \\
\text { final haul out }\end{array}$ & 8 & $8: 55$ & 162 & 91 & 109 & 311 & 132 & 248 & 37 & 32 \\
\hline & Average & 5.3 & & 146.8 & 98.9 & 123.2 & 215.0 & 166.0 & 297.7 & 44.3 & 27.0 \\
\hline & $\begin{array}{l}\text { Standard } \\
\text { Deviation }\end{array}$ & 3.2 & & 15.6 & 34.1 & 40.6 & 117.5 & 92.3 & 164.7 & 35.3 & 21.0 \\
\hline
\end{tabular}




\subsection{Mobilization of crab-pot-strings}

To determine the chance part of the risk, we approximated the probability of mobilization of crab-potstrings anchored with regular Bruce anchors. It was a very windy summer in 2021 (Section 3.1). We have had several periods with Bft 7 and also maxima to $18 \mathrm{~m} / \mathrm{s}(=8 \mathrm{BFt})$. Out of $120(10 * 6 * 2)$ times, only once an anchor has moved in the period from 01-08-2021 to 11-08-2021 with a maximum wind force of $18 \mathrm{~m} / \mathrm{s}$. It turned out to be tangled in its own rope. That side of the crab-pot-string moved 40-50m, the other side did not. In the following deployments the anchor and dhan that had been mobilised did not move again.

\subsection{Species, catchment \& saturation curves}

\subsubsection{Species caught}

Of the main species of interest, only three European lobsters were caught (at the Adder and the Houtrust). A total of 757 brown crab was caught: 334 females and 406 males and 17 where sex was not registered (with $5 \mathrm{CW}$ measured and 12 not). Mean CW was 12.2 for females and 12.6 for males (statistically not different) (Table 3, Figure 4).

For the velvet swimming crab only sex was determined (237 females; 302 males and 30 undetermined, yielding a total of 569, Table 4). Two females carried eggs. Other potentially commercially important species caught in some amounts was common cuttlefish (Sepia officinalis, 15 specimen). Common seastar (Asterias rubens) was caught numerous. On an incidental level the following species were encountered: Atlantic cod (Gadus morhua: 1 specimen), common shore crab (Carcinus maenas), tub gurnard (Chelidonichthys lucerna), dab (Limanda limanda), harbour crab (Liocarcinus depurator), grey swimming crab (Liocarcinus vernalis), common monkfish (Lophius piscatorius), Atlantic spinous spider crab (Maja brachydactyla), striped red mullet (Mullus surmuletus), bull rout (Myoxocephalus scorpius), common brittlestar (Ophiothrix fragilis), hermit crab (Pagurus bernhardus), pouting (Trisopterus luscus) and viviparous eelpout (Zoarces viviparus), all in low numbers.

\begin{tabular}{|c|c|c|c|}
\hline Category & CW mean & Standard error & $n$ \\
\hline Female & 12.2 & 2.3 & 334 \\
\hline Male & 12.6 & 2.9 & 406 \\
\hline Undetermined sex & 12.2 & 3.4 & 5 \\
\hline No CW & & & 12 \\
\hline Total & & & 757 \\
\hline CW >12.9 (\# landable) & & & 296 \\
\hline Landable (\%) & & & $39 \%$ \\
\hline
\end{tabular}




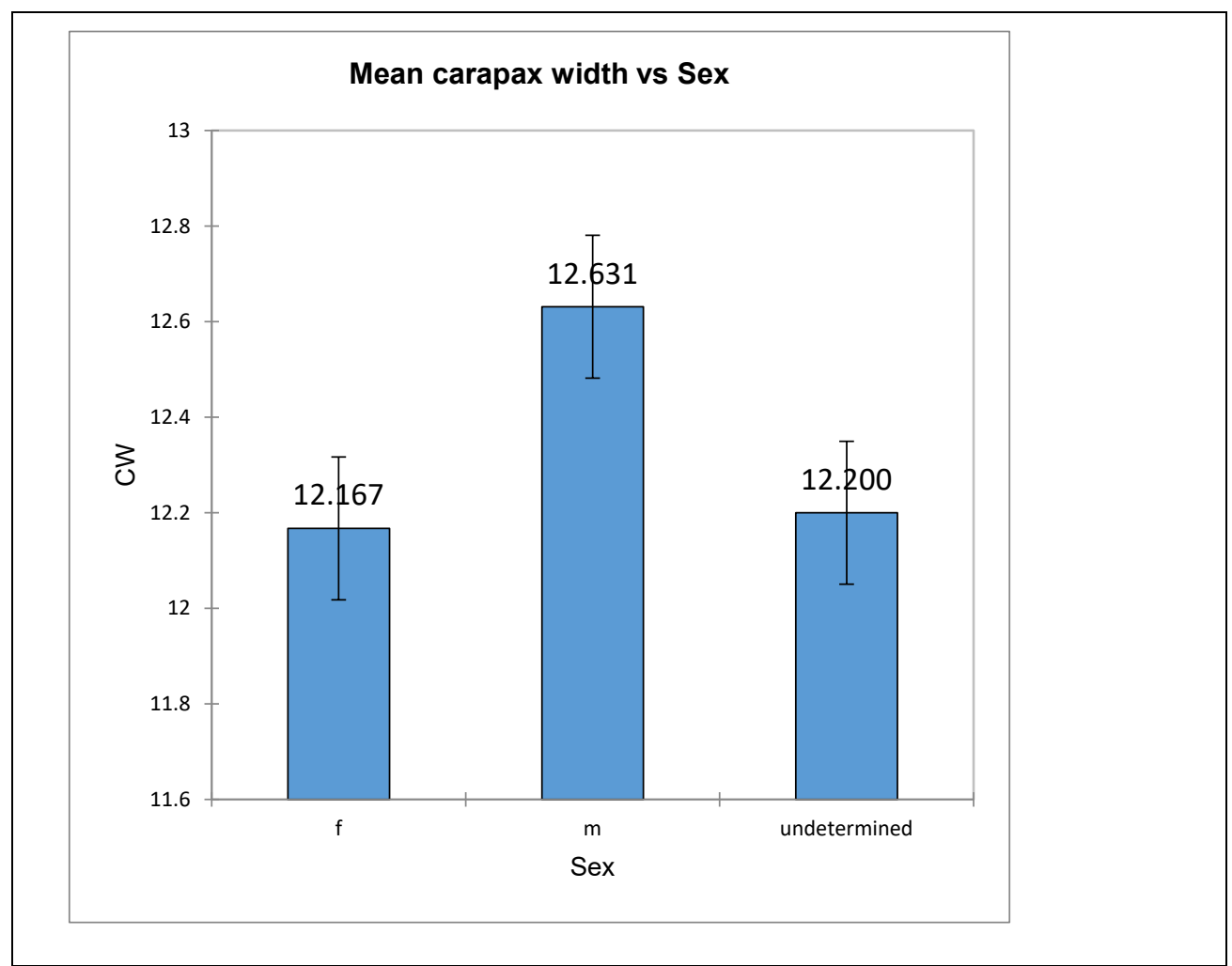

Figure 4 mean carapace width (CW) versus sex of the brown crab.

\begin{tabular}{|l|l|r|r|r|r|}
\hline \multicolumn{1}{|c|}{\begin{tabular}{l} 
Table 4 Number and female and male distribution of the most important species caught. Also un- \\
sexed specimens are given \\
\hline \multicolumn{1}{|c|}{ Name }
\end{tabular}} & \multicolumn{1}{|c|}{ Latin name } & female & male & $\begin{array}{c}\text { Undetermin } \\
\text { ed sex }\end{array}$ & $\begin{array}{c}\text { Total } \\
\text { number }\end{array}$ \\
\hline common lobster & Homarus gammarus & 2 & & 1 & 3 \\
\hline brown crab & Cancer pagurus & 334 & 406 & 17 & 757 \\
\hline velvet swimming crab & Necora puber & $* 237$ & 302 & 30 & 569 \\
\hline Atlantic cod & Gadus morhua & & & 1 & 1 \\
\hline common cuttlefish & Sepia officinalis & & & 15 & 15 \\
\hline
\end{tabular}

*: 2 with eggs

\subsubsection{Catchment in time}

For two species, having sufficient data, catchment curves were determined: brown crab and velvet swimming crab. For brown crab tagged animals were recaught, indicating it is possible to start to calculate population estimates (not done in present study). Also some incidental velvet swimming crab were recaught that were tagged for training purposes of participating crew members.

\section{General data exploration}

All experiments mounted to $9 * 6 * 5=2570 \mathrm{crab}$ pots measured. Of these, 73 out of 270 pots $(27.0 \%)$ showed no $C$. pagurus, and 61 out of 270 pots (22.6\%) showed no N. puber (Figure 5). In terms of strings, $3.7 \%$ showed no C. pagurus, and $1.9 \%$ showed no $N$. puber. 


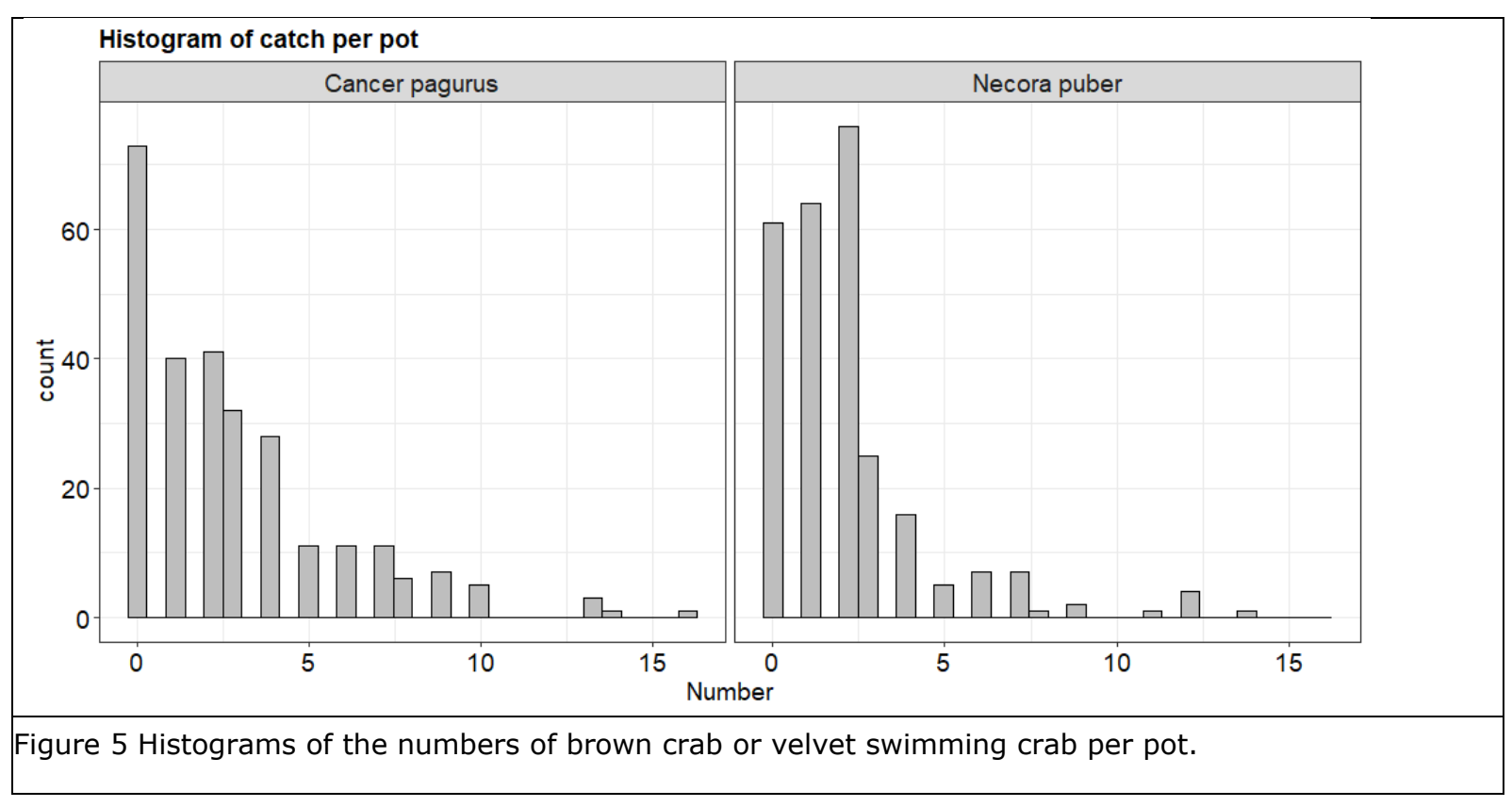

\section{Brown crab}

Data were analysed by means of GLM. The best fitted model includes the interaction between wreck and side. (Wreck * Side + soak time1 + Normalised.pot.no + Type.of.pot). The tested p-values of these covariates are given in Figure 6 and Table 5. The estimated effects are illustrated in Figure 6. The strongest factors that determines catch numbers are location (i.e. wreck-side) and soak time.

Overall Adder wreck has the highest catch of $C$. pagurus. For both Adder and Houtrust, the west side is slightly higher than the east side. Key West has the lowest catch among the 3 wrecks, and its west side is lower than the east side. The catchment strongly increased from 1 day to 7 days soak time and then levelling to a plateau till the 10 days. Additionally, the catch rate seems to increase from the south (pot position 1) to the north (pot position 5), This is less likely to be caused by the type of pot, which showed no significant effect (Figure 6 and Table 5).

\begin{tabular}{|l|l|}
\hline $\begin{array}{l}\text { Table } 5 \text { tested covariates to explain the variance in catchment of Cancer pagurus with strings with } \\
\text { pots }\end{array}$ \\
\hline covariates & p-value \\
\hline Wreck $*$ side & $<0.001$ \\
\hline Soak time & $<0.001$ \\
\hline Normalized pot position & $<0.001$ \\
\hline Type of pot & 0.90 \\
\hline
\end{tabular}




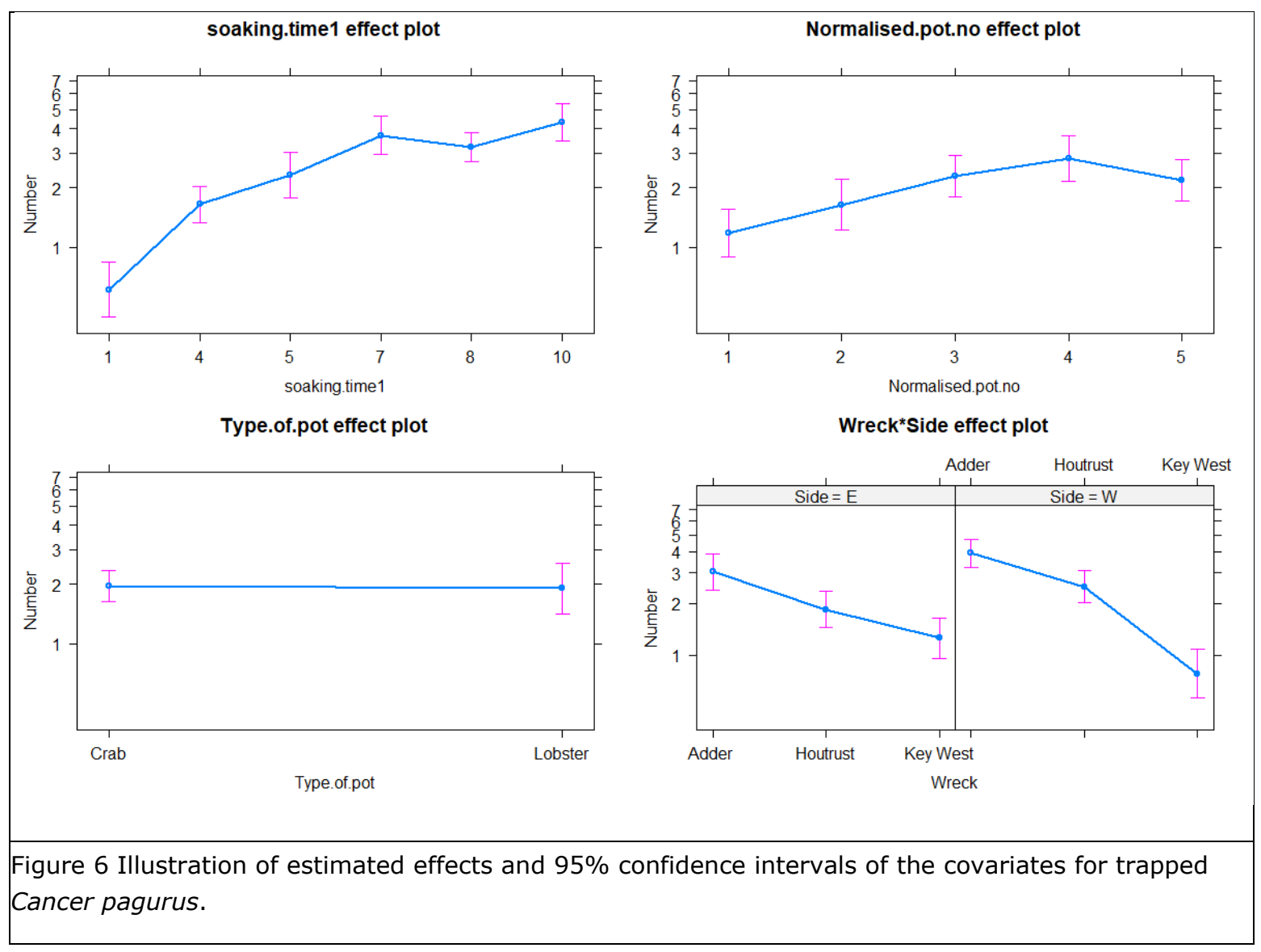

\section{Velvet swimming crab}

The results of catchment of the velvet swimming crab are given in Table 6 and Figure 7. The best fitted model includes the interaction between side and soak time. (Wreck + Side * soak time, Table 6) The strongest factors that determines catch numbers are Side of the wreck (east or West) combined with soak time. Both pot position and type of pots showed no significant effect on catch number.

Unlike brown crab, swimming crab catch number is much less associated with wreck. Instead $N$. puber is more sensitive to side and soak time: On the west side, the catchment increased with the soak time and starts to drop after 7 days with a large drop between 8 and 10 days. On the east side, the trend is less clear, seemingly to reach maximum levels after 4 days. Overall the catch rate for N. puber is lower than $C$. pagurus on all 3 three wrecks, and it has a slightly higher catchment in Houtrust (though not significant). The increase of catchment from South to North (pot position) as was seen for brown crab, appeared not significant for velvet swimming crab.

\begin{tabular}{|l|l|}
\hline \multicolumn{2}{|l|}{$\begin{array}{l}\text { Table } 6 \text { tested covariates to explain the variance in catchment of Necora puber with strings with } \\
\text { pots }\end{array}$} \\
\hline covariates & p-value \\
\hline Side* soak time & $<0.001$ \\
\hline Wreck & $<0.001$ \\
\hline Normalized pot position & 0.11 \\
\hline Type of pot & 0.55 \\
\hline
\end{tabular}




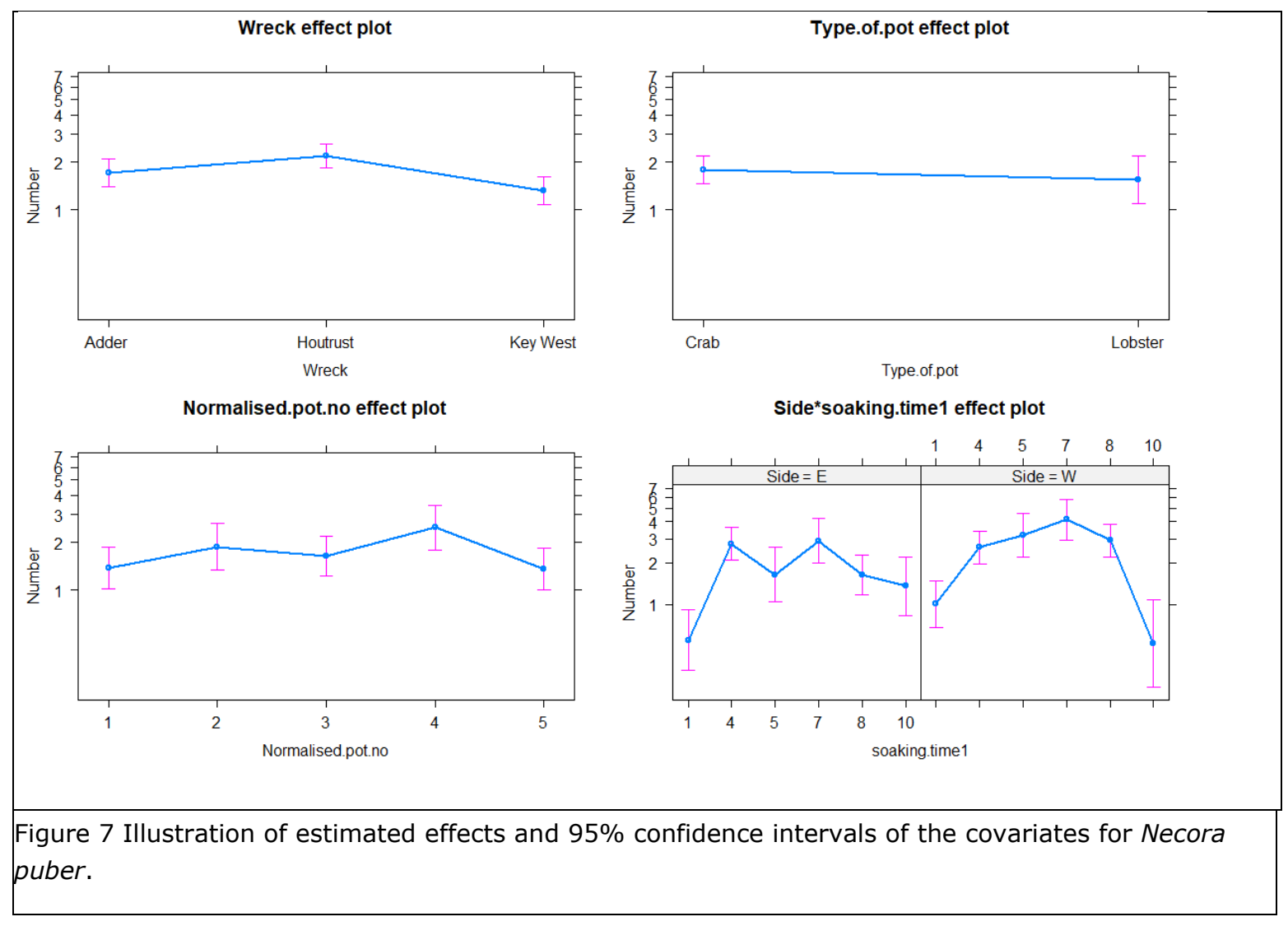

\subsubsection{CPUE}

Mean CPUE and its standard deviations was calculated as number per day per pot for each species (Figure 8). The variations of CPUE at day 1 was high, resulting in higher standard deviation at day 1 for both species. For $C$. pagurus, the CPUE was reasonably constant over soak time, and it differs among wrecks (Figure 8): overall around $0.91 \mathrm{crab}$ per day per pot were caught near the Adder; 0.57 per day per pot near the Houtrust; 0.22 per day per pot near the Key west.

Overall CPUE for N. puber was lower than C. pagurus and showed similar constant trend over soaking time. At day 10, CPUE was lower, but still within the uncertainty bands of earlier days (Figure 8 ).

Overall around $0.46 \mathrm{~N}$. puber per day per pot were caught at the Adder; 0.60 per day per pot near the Houtrust; 0.39 per day per pot near the Key west. Since the CPUE curves are flat for both species, it is difficult to find an optimum soak time from this point of view. 


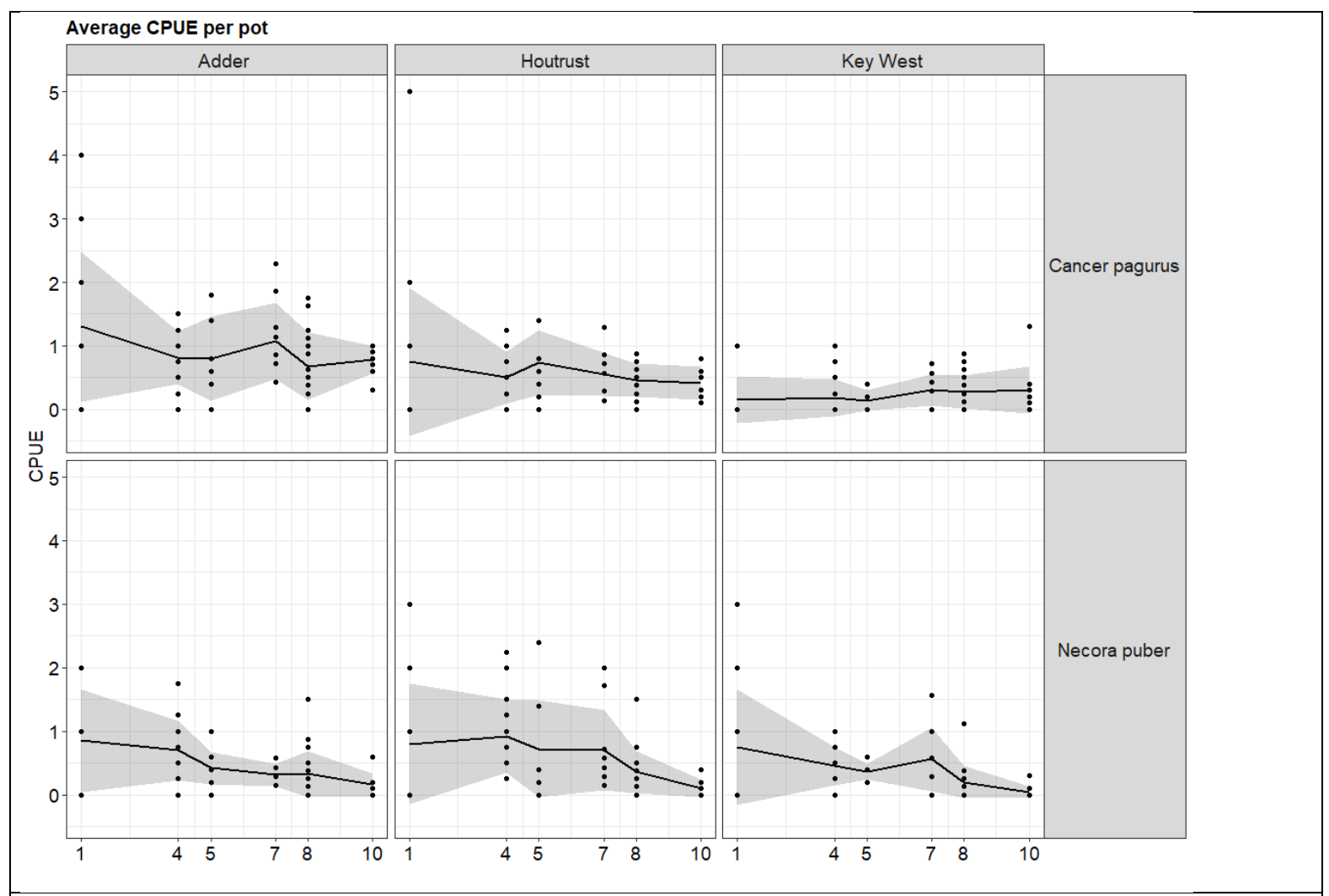

Figure 8 CPUE for brown crab (Cancer pagurus) (top row). And Velvet swimming crab Necora puber at three different wrecks (bottom row). Bands represent standard deviation.

\subsubsection{Mark and recapture}

Of the 756 brown crab caught, 724 were tagged (95.6\%). The non-tagged brown crabs were either too small or soft or too damaged. A number of 26 tagged brown crab was recaught (3.4\%). A steady increase in recaptured brown crabs is seen versus soak time with an unexpected 0 recaptured brown crab after 10 days soak time (Figure 9).

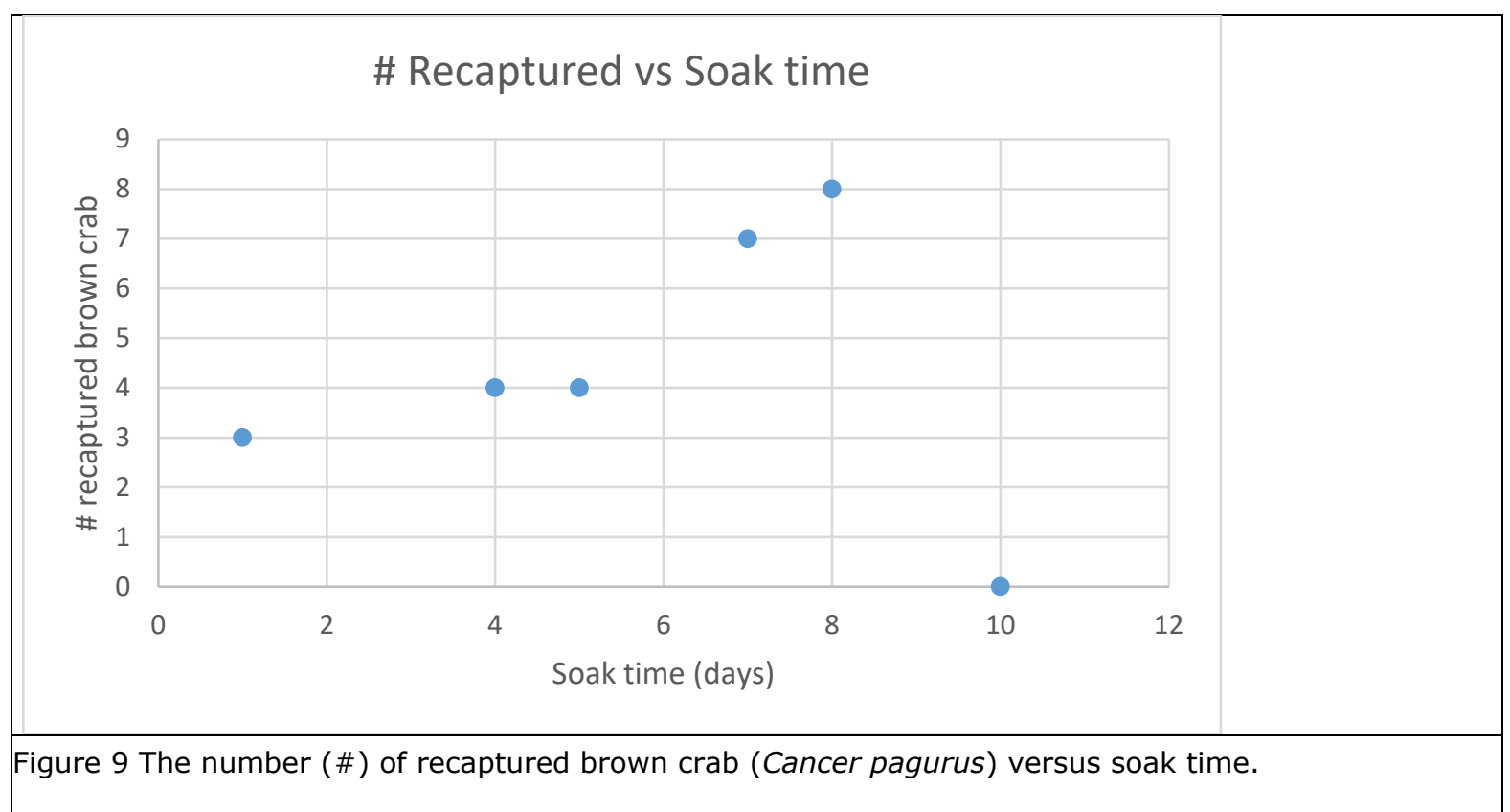




\section{Discussion}

\subsection{Weather summer 2021}

After three very warm summers, the temperature this summer was normal. It averaged $17.7^{\circ} \mathrm{C}$ against a long-term average of $17.5^{\circ} \mathrm{C}$. The season was less sunny than usual and on the rainy side, although the precipitation was unevenly distributed over the sea and country. There was a weak and therefore strongly undulating jet stream ${ }^{3}$, becoming strong at the beginning of August, running southwards of the Netherlands with a small tail in the measurement area, resulting northern air masses and relatively turbulent weather. ${ }^{4}$ Winds were generally strong given the 4 periods in which $\geq 7$ Bft ( $\geq 13.2 \mathrm{~m} / \mathrm{s})$ occurred.

Weather and water data were obtained from Hoek van Holland, E13 and Lage Licht weather stations. These data are most accurate although shore bound. In principle these stations serve well as a proxy. Caires \& Pathirana (2019) concluded from analysing weather and water data that all stations correlated well.

Hoek van Holland weather station is on shore. As compared to sea, measured variables are lower. E.g. maximum wind speed was $9.0 \mathrm{~m} / \mathrm{s}$ at Hoek van Holland ${ }^{5}$ whereas at Europlatform it was $10 \mathrm{~m} / \mathrm{s}$ and $11 \mathrm{~m} / \mathrm{s}$ at $\mathrm{K}_{13 \mathrm{~A}^{6}}$. Hoek van Holland weather station was used because it is the most accurate monitoring station with also best performance end certainty (A. Korving, Rijkswaterstaat, pers. experience). Any implementation measure related to wind velocity to perform passive fisheries in PAWP should be related to predictions at this weather station.

As compared to Rozemeijer et al. (2022a) the encountered weather and water conditions in 2021 were alike the conditions in 2019 and 2020 (Table 7) when dahns and fenders were tested with chain bunches instead of Bruce anchors. The maximum wind velocity was even higher in 2021. Also data where the strings were not -mobilised, were given. Maximum water level compared to NAP yielded the coherent relation with displacement of the crab-pot-strings with dahns and chain bunches. It is in each case clear that the circumstances resulting in mobilising strings with dahns and chain bunches did not result in mobilising strings with dahns and Bruce anchors. Maximum water level compared to NAP represents both an indicator for currents as well as higher water levels providing more strain to the dahn and line thereby being able to lift the chain bunches from the seabed.

3 A narrow variable band of very strong predominantly westerly air currents encircling the globe several miles above the earth.

4 https://vakantieweer.nu/ook-straalstroom-lijkt-zich-met-ons-te-koele-weer-te-gaan-bemoeien/ d.d. 30-11-2021

https://www.meteo.be/nl/info/weerwoorden/straalstroom d.d. 30-11-2021

5 https://www.knmi.nl/nederland-nu/weer/actueel-weer/kust-en-noordzee (27-12-21).

6 The Europlatform is located in the North Sea, approximately $30 \mathrm{~km}$ SWW from Hoek van Holland. K13A is an offshore production platform located $\sim 100 \mathrm{~km}$ WNW from Den Helder, the Netherlands in the Southern North Sea. Both serve as KNMI monitoring locations where real-time measurements are performed. 


\begin{tabular}{|c|c|c|c|c|c|}
\hline & Unit & \begin{tabular}{|l} 
Minimum \\
level at \\
mobilisation \\
20192020 \\
\end{tabular} & $\begin{array}{l}\text { Maximum } \\
\text { level at } \\
\text { mobilisation } \\
20192020 \\
\end{array}$ & $\begin{array}{l}\text { Level at non- } \\
\text { mobilisation } \\
20192020\end{array}$ & 2021 Maximum \\
\hline $\begin{array}{l}\text { Maximum wind } \\
\text { velocity }\end{array}$ & $\mathrm{m} / \mathrm{s}$ & 9.4 & 17.5 & 11.7 & 18.0 \\
\hline $\begin{array}{l}\text { Maximum } \\
\text { significant wave } \\
\text { height }\end{array}$ & $\mathrm{cm}$ & 99 & 337 & 167 & 298 \\
\hline Maximum swell & $\mathrm{cm}$ & 9 & 90 & 32 & 61 \\
\hline $\begin{array}{l}\text { Maximum water } \\
\text { level compared to } \\
\text { NAP }\end{array}$ & $\mathrm{cm}$ & 121 & 207 & 121 & 162 \\
\hline
\end{tabular}

\subsection{Mobilization of crab-pot-strings}

The crab-pot-strings were not mobilised by any of the weather conditions encountered. Only one anchor was set loose under the most severe circumstances. On hauling out it appeared that this anchor was entangled in its own line. The other anchor proved sufficiently resistant to keep the string in position, even though a wind force of $8 \mathrm{Bft}$ and $158 \mathrm{~cm}$ Maximum water level to NAP resulted in severe pulling forces on dahns and strings. To prevent entangling in the future it seems advisable to have only one anchor on each side and not connect two anchors to each other with a line. This would increase the change of anchors and lines entangling and thereby reducing holding power of the string as a whole.

The normal Bruce anchors pose a very low risk (1). In terms of risk categorisation, the chance of a crab-pot-string mobilised is extreme low for wind forces up to $18 \mathrm{~m} / \mathrm{s}$ ( $8 \mathrm{Bft}$ at Hoek van Holland): Change $=1$ (May never occur). The damage $D$ was assessed in Rozemeijer et al. $(2022 a, b, c): D=1$ (Negligible: No or insignificant damage to equipment or materials). The risk can be estimated to be 1 $(R=c * D=1 * 1=1)$.

\subsection{Catchment of brown crabs, lobster and bycatch}

\subsubsection{Wrecks}

Three wrecks were chosen as location for these tests: Zr.Ms. Adder, Key West and Houtrust. Both Zr.Ms. Adder and Houtrust are fairly large ships and made of metal. For Zr.Ms. Adder is clearly high above the seabed and offers ample space for brown crab (Figure 11). Houtrust was in 2011 well above the sand (Figure 12). Given the size, one can expect it to be still above the seabed and to offer suitable substrate. Key West is the least suitable for crabs, being mostly submerged in the sand (Figure 13). This also becomes clear from the statistical analysis showing the same pattern for the crevice preferring brown crab (Figure 6, Table 5).

In addition, pot 3 of each string was placed at the middle of each wreck. The fact that a pot is still near a wreck (pot 2 and 4 of the Zr.Ms. Adder) could help explain the significance of the pot position 
in the statistical analysis (Figure 5, Table 5) though bait scent cloud in relation to currents might be a large factor as well.

\subsubsection{Brown crab}

\section{MSL, male, female}

Brown crab was caught in the largest number in almost equal numbers of males and females. Mean CW was near $12.3 \mathrm{~cm}$, from which $39 \%$ was passing the minimum landing seize limit (MLS) of $13.0 \mathrm{~cm}$ (Tonk \& Rozemeijer, 2019). In general less females are caught because females carrying eggs dig sand pits and remain there for several months (CEFAS, 2020). In this study, almost equal amounts of females and males were caught, maybe because the tests were performed after the hatching period (Tonk \& Rozemeijer, 2019). Comparing regions with catchments in the same period, Bennet (1974) observed 40* more females in august (Devon, UK). Stelzenmüller et al. (2021), on the contrary, encountered 4.8 more males (in June and August, in the German Bight). Apparently there is a strong regional aspect to behaviour and catchability. Of course one can expect seasonal influences as well but these are not strong in the short period the measurements of present study have been performed (Bennet, 1974, Tully et al., 2006, Öndes et al., 2019).

\section{Soak time}

Figure 6 shows a Holling II type of curve for total amount of brown crab caught versus soak time. This type of curve is usually encountered. Owing to trap saturation and declining bait attractiveness, trap catches have an asymptotic relationship with soak time (Spencer, 2013, Skerrit et al., 2020).

Catchability of an individual animal depends on size, sex, moult status, and rhythms (like day : night, seasonality) and environmental factors such as location, light, water temperature and currents, and also factors such as vessel and crew characteristics (Miller, 1990, Skerrit, 2014, Öndes et al., 2019).

Present study showed a saturation in catchment starting at 7 days (Figure 6). Wolf et al. (2006) found catchment saturation after 2 days (Norway, mostly August to November). Tully et al. (2006) found a saturation of Landings Per Effort Unit (LPUE, only the landable brown crab) at 4 to 6 days in January, North Western Ireland (ICES rectangle 39E0). Lovewell et al. (1988, Yorkshire, UK, August) observed a strong reduction in CPUE from day 1 to 3 (even a reduction in catch in some cases), indicative of saturation.

As stated above, local circumstances dictate the duration to reach saturation in a pot. Given the diversity, a soak time of 7 days to reach saturation is in line with other results. Sundberg (1985) argued longer soak time ( $>1,2$ days) would improve the bait smell yielding a potential explanation that longer soak times are better in our case.

\section{CPUE}

CPUEs are subject to uncertainties due to additional factors, such as state of the individual animal, escapements, gear design selectivity, trap spacing, density and saturation effects, species interactions, bait, changing area of bait influence or attractiveness and environmental factors (Bennet, 1974, Miller 1979, 1990, Sundberg, 1985, Lovewell et al., 1988, Fogarty \& Addison 1997; Bell et al. 2001; Ziegler, Frusher et al. 2003, Montgomery 2005, Reidenbach \& Koehl, 2011, Öndes et al., 2019, Skerrit et al., 2020).

During this period the CPUE ranged from 0.3 to 1 crab per pot per day for the period 1-8-2021 to 189-2021. Steenbergen et al. (2012) measured a CPUE of 0.3 to 0.6 at the Texelse Stenen near Texel and Vlieland, also in August, September. Stefan Tijsen (fisher using crab pots) estimated he caught 1.7 crab maximally per pot per day at the Texelse Stenen above Vlieland and Terschelling in summertime (pers. comm.).

Bennet (1974) measured a CPUE of approximately 0.3 to 1.6 for males and 0.5 to 5.7 for females (depending on season, assuming a crab to weigh $0.454 \mathrm{~kg}$ ). Lovewell et al. (1988) had CPUEs ranging from 0.28 to 2.81 , depending on pot type and soaking time, at Yorkshire, UK. Bell et al. (2003) calculated an CPUE of 2.74 per tide (one low and high water period) which is roughly 5.5 brown crabs per pot per day at the Race Bank, north Norfolk also in the months August, September. Spencer 
(2013) had an average CPUE of 1.79 per tide which is roughly 3-4 crabs per pot per day (4-22 brown crabs per pot) near Seaton Sluice (UK). Wolf et al. (2006) found various CPUEs ranging from 3.6 to 13.4 at various locations in Norway with habitats ranging from exposed (ocean) to sheltered (fjords and protected grounds leeward of large islands). Öndes et al. (2019) calculated an average CPUE of 7 to 8 brown crabs per pot, depending on type of pot, type of bait and boat, moment of the year (Isle of Man, northern Irish Sea). Stelzenmüller et al. (2021) found an average CPUE of 14.5 brown crabs (June and August) in transects an OWF located near the island of Helgoland (German Bight, the better area for brown crab, Tonk \& Rozemeijer, 2019)

Concluding, with a CPUE of 0.3 to $1 \mathrm{crab}$ per pot per day the results of present study are on the lower side. The average density of brown crabs on the soft substrate of the DCP is was estimated at 0.2 to 6.3 number of crabs per hectare (nha) (Tonk \& Rozemeijer, 2019). Given the fact that the optimal habitat of hard substrate is limited (only the wrecks), and the Key West is almost gone, a low CPUE seems in line with the local setting and conditions.

\section{Pot-position}

Table 5 shows pot position is also significant: northward pots are more favoured. Presumably this reflects the extent and shape of the bait scent plume. During a tide the current direction develops from $\sim 244^{\circ}$ low tide to $069^{\circ}$ at e.g. Hoek van Holland (location dependent) at hightide and then back (Inleiding getijtafels ${ }^{7}$ ). And with a stronger high tide current than a low tide current, it is imaginable that the bait scent plume is oriented towards the north thereby attracting more animals to the northern pots (Sunberg, 1985, Reidenbach \& Koehl, 2011). For this reason, fishermen at the Texelse Stenen place their strings perpendicular to the currents, to have an as large as possible bait scent plume that envelops the maximum number of pots (Tonk \& Rozemeijer, 2022, in prep., Stefan Tijssen, PFA, pers. comm.). A major disadvantage for a potential application of perpendicular orientation of the crab-pot-strings in PAWP is that it is very difficult to place the crab-pot-strings at agreed positions.

Another aspect of bait scent plume is the bait used. Horse mackerel has been tested as a very good bait (Steenbergen et al., 2012). Being a soft tissue fish, it will lose structure within a couple of days. It is advised to combine both horsemackerel and the tub gurnard, Chelidonichthys lucerna which has a firm tissue, and therefore stays intact longer.

\section{Mark and recapture}

With an increasing soak time increasing numbers of tagged brown crab were recaptured with 8 days a maximum (Figure 9), apparently the effect of accumulation. Remarkably, at 10 days no tagged crabs were caught. There is no clear explanation for this phenomenon. Figure 6 showed no indication of predation of brown crab as it did e.g. for velvet swimming crab (Figure 7). The results suggested that an optimal soak time would be 7-8 days to maximize recapture of tagged brown crab.

Bell et al. (2003) used the technique for a similar purpose but did not give recapture percentages. Spencer (2013, Blyth UK in November, comparable small scale set up of the test lasting 6 weeks), calculated a $3.8 \%$ recapture percentage of 3,718 brown crab, low but sufficient for estimating populations. That number is comparable to the $3.4 \%$ of present study. Hunter et al. (2013) had a $17 \%$ to $40 \%$ recapture percentage of 128 testing animals for a migration research, large of scale in time (lasting almost one year) and space (Chichester to Falmouth, south coast of the UK). They also offered a substantial reward to commercial fishermen. Ungfors et al. (2007) also measure a 8.0 $8.7 \%$ recapture percentage for large scale migration research $(3,749$ crabs tagged, 7 years and Skagerrak and Kattegat, mark and recapture experiment). Coleman et al. (2017) had a recapture percentage between 0.6 to $22.4 \%$ for a 4 -year, large scale migration experiment $(6,954$ brown crab tagged) at the Orkneys with dedicated fishermen.

\footnotetext{
${ }^{7}$ https://docplayer.nl/26297701-Inleiding-getijtafels.html d.d. 9-12-2021
} 


\subsubsection{Velvet swimming crab}

The velvet swimming crab $N$. puber (L.) is thought to be a main by-catch species for OWF multi use cases (van de Boogaard et al., 2019). In present study, similar amounts were caught with almost the same catchment characteristics as brown crab (compare Table 5 with Table 6 and Figure 6 with Figure 7). Skerrit et a. (2020) encountered similar results for the inshore potting area off Northumberland, UK, velvet swimming crab being a potential resource, like Roach (2019) for the Westermost Rough OWF, UK, near the Humber estuary (before and after placement of the OWF). Velvet swimming crab are cautious to enter a trap when European lobsters or brown crab are already present in a pot (Skerrit et al., 2020). Roach (2019) argued velvet swimming crab occupies the same ecological niche as brown crab and could replace brown crab if the latter is caught in excessive amounts.

The most conspicuous aspect of the soak curve of the velvet swimming crab is the drop after 8 days (Figure 7). This could be either due to escapement of the smaller velvet swimming crab or predation of this species by the larger brown crab.

Wallace \& Rae (2018) measured a CPUE of 0.24 for pots without an escape gate and CPUE of 0.06 for pots with an escape gate. For the Westermost Rough OWF and control area a range 0.5 to 3 velvet swimming crabs per pot per day (CPUE) were measured (over several years and areas, Roach, 2019, Roach \& Cohen, 2020). These results are comparable to the CPUEs of present studies (0.39 to 0.6).

Concluding velvet swimming crab could be an important exploitable by-catch. If targeted, it is important to use pots without escape gates and to reduce soak time.

\subsubsection{Other bycatch}

Sepia was the only other commercial bycatch that was caught occasionally. The common sea star was frequently encountered, however this is not a species of interest. Presumably bycatch is region and season dependent. Roach \& Cohen (2020) encountered more species which could be related to the studied habitat (one of the richest lobster habitats of the UK with ample hard substrate). 


\section{$5 \quad$ Conclusions and recommendations}

This study is a sequel of the project BO-43-119.01-012 KD-2021-018_Alternatieve ankers in windparken op zee in which adapted anchors were investigated for suitability of passive fisheries with crab-pot-strings in OWFs in general and PAWP in particular.

Fishing, working and manoeuvring within OWFs is very different from fishing outside OWFs in the North Sea. There are additional conditions and high requirements to allow other activities in OWFs. Knowledge is required of the risks that can occur when, for example, setting up crab-pot-strings in an OWF. Reducing operational risks for fishing in the particular case of PAWP has a high priority from a safety and liability perspective. In this project we studied both aspects of risks of anchoring strings for infield electricity cables of PAWP and the suitability of the set up to catch brown crab (C. pagurus) and European lobster (H. gammarus).

\subsection{Chance of mobilising strings with anchoring}

After extensive research (Rozemeijer et al., 2020, 2021, 2022a,b,c, Korving et al., 2021) it was determined that crab-pot-strings need to be fixed to the seabed with normal anchors when fishing in PAWP. Thereto it was necessary to assess the risk of anchors hooking in infield-electricity-cables. Risk is chance * damage $\left(R=c^{*} D\right)$. Present study has focussed on the chance part $(c)$ : do crab-pot-strings with anchors get mobilised under different current and weather conditions occurring during summer?

To determine the risk, we approximated the chance $c$ of mobilization of crab-pot-strings anchored with regular Bruce anchors. It was a very windy summer in 2021. Several periods of wind force Bft 7 and up to $18 \mathrm{~m} / \mathrm{s}$ wind velocity (=8 BFt) were measured at Hoek van Holland weather station. Out of 120 $(10 * 6 * 2)$ times, only 1 anchor has moved. It turned out to be tangled in its own rope. That side of the crab-pot-string was moved 40-50m, the other side was not. Concluding: the chance that a crab-potstring is mobilized at wind force $7 \mathrm{Bft}$ and lower range of $8 \mathrm{Bft}$ is very low (independent of the number of anchors per side).

Given the fact that two anchors on the same side have a higher chance to become entangled and the risks on board with extra wires and thereby personal being pulled overboard, it is not advisable to work with double anchors at each side of the crab pot string.

The normal Bruce anchors poses a very low risk (1). In terms of risk categorisation, the chance of a crab-pot-string mobilised is extreme low for wind forces up to $18 \mathrm{~m} / \mathrm{s}$ ( $8 \mathrm{Bft}$ at Hoek van Holland): Change $=1$ (May never occur).

The risks of passive fisheries with crab-pot-strings equipped with dahns and Bruce anchors in OWFs is acceptable up to $18 \mathrm{~m} / \mathrm{s}$ wind force: no chance of moving.

\subsection{Catching brown crab, velvet swimming crab and other animals}

It appeared possible to catch brown crab and velvet swimming crab in amounts. European lobster was hardly caught at the three wrecks. Other species of interest could be sepia which was caught in low amounts

\subsubsection{Saturation vs soak time}

Both brown crab and velvet swimming crab reached a saturation in pot loading after $\sim 7$ days. These results are comparable to other soak time results. It suggests that the period between the hauling of 
crab pot strings (soak time) can be on the higher side ( $\geq 4$ days), to optimise the catchment of tagged animals. However, wind and wave conditions in the summer of 2021 required revision of the original planning after every expedition. In addition, earlier experiences showed that wind conditions can deviate from the general patterns (alike other authors, e.g. Spencer, 2013, Skerrit, 2014). It seems better to plan trips with 4-7 days interspace (taking Mark and recapture results in account) but to be flexible in these dates which allows to adjust to circumstances as they happen and take the opportunities offered.

\subsubsection{CPUE}

With a CPUE of 0.3 to $1 \mathrm{crab}$ per pot per day the results of present study are on the lower side compared to other research. A potential cause could be the amount of suitable substrate: in this case a wreck on soft sediments. The average density of brown crabs on the soft substrate of the DCP is low (Tonk \& Rozemeijer, 2019). Given the fact that the optimal habitat of hard substrate is limited (only the wrecks offer hard substrate), and the Key West is almost covered by the seabed, a low CPUE seems in line with local circumstances. Other auteurs performed their research at renowned crab grounds with ample hard substrate. In addition, the extent and shape of the bait scent could have been of significance to explain the lower CPUE as compared to similar reseacrh.

Velvet swimming crab CPUEs were more in line with results obtained by others (Wallace \& Rae 2018, Roach, 2019, Roach \& Cohen, 2020).

\subsubsection{Pot position}

The pot position was of significance. The most likely cause is that the characteristics of the tidal currents have directed most of the bait scent plume towards the northern pots. In PAWP crab-potstrings will be parallel to the currents (Rozemeijer et al., 2020) and on the northern site of the monopiles: a non-favourable position. To improve bait scent plume tub gurnard will be added. In addition, an evaluation will be started with Eneco after the anticpated tests of 2022 whether it is possible in a much later stage to position the crab-pot-strings perpendicular to the currents.

\subsubsection{Other bycatch}

Other bycatch was not relevant in present study. Also European lobsters had a minor contribution to the total catch. Registration of total bycatch will continue in the PAWP experiment adding also the measurement of the CW of velvet swimming crab (using $6.8 \mathrm{~cm}$ as MSL). It is anticipated that catch of European lobster will not be enough to be of economic importance in PAWP (Rozemeijer \& van de Wolfshaar, 2019).

\subsubsection{Mark and recapture}

Tagged brown crab were recaught. Similar recapture percentages were obtained in a similar study. The recapture percentages are low, but could serve to do population estimates.

\subsubsection{Overall conclusion on catching crab and lobster}

It is possible to catch crab and other species with this set-up. The use of anchors does not hamper catchment. Tagged animals were also recaptured proving the validity of the approach of Catch : Mark : Recapture. Most potential for improvement for the set-up seems to lie in the orientation of the crabpot-string to the orientation of the currents (perpendicular or parallel).

\subsection{Recommendations}

A number of recommendations can be made. The following sections list a non-exhaustive selection. 


\subsubsection{Chance of mobilising Bruce anchors}

A lot of research has been done on the subject of anchoring the crab-pot-strings with different means. The major questions are still in the mobilisation part. Now wind maxima of $18 \mathrm{~m} / \mathrm{s}$ have been assessed. There was no movement in the strings. More extreme conditions could be assessed as well, e.g. by deploying strings in autumn or spring in order to have higher chances on more extreme conditions. Given the fact that an implementation measure of retrieving the crab-pot-strings from PAWP is anticipated based on wind velocity, the normative wind velocity could increase with new results thereby increasing the wind window in which the crab-pot-strings can remain in PAWP.

Bruce anchors are very effective anchors for sandy seabed like the Dutch coastal zone. In addition Bruce anchors are affordable for fishermen. Based on present results there is no need to check other anchors for the application with crab-pot-strings. For other applications which are not easily removed or that remain in the sea over winter and will therefor endure much harsher conditions (like e.g. aquaculture installations), other (modern) anchors could be studied like the Rocna anchor or heavier Bruce anchors.

\subsubsection{Crab fisheries}

Scientific passive fisheries in PAWP will be the first passive fisheries in an OWF in the Netherlands. Based on the results of present study major questions arise on soak time, CPUE, recapture, population estimates and species of interest on other Dutch locations. These questions will be dealt with as a natural result of upcoming expeditions. Also average seize is important and LPUE. Krone et al. (2017) found much smaller brown crab than encountered on the wrecks and suggested OWFs are nursery areas. In this sense both CPUE and LPUE need to be assessed for a business model of passive fisheries on crab in OWFs.

More experience should be gained on the application of the Catch : Mark : Recapture technique for brown crab. For European lobster several publications can be found. For brown crab only two dedicated publications were found. It is wise to apply the technique not only in PAWP but other locations as well.

Additional attention needs to be focused on the velvet swimming crab. Numbers were such that it is worth to measure CW as well and determine LPUE next to CPUE.

A need to know aspect for the future is the positioning of the crab-pot-string towards the currents. Now a set-up is defined parallel to the currents because safety considerations on deploying the crabpot-string, need for precise locations and implications for the CTV. Discussions with Stefan Tijssen suggested that, with a larger ship (e.g. $20 \mathrm{~m}$ shrimp cutter), deploying perpendicular to the currents is just as safe for the ship as parallel to the currents. Given the significance of pot position, in a later stage, other set-ups could be investigated in addition to what is agreed in the Wok Method Statement for PAWP (Rozemeijer et al., 2020).

Major questions arise on the sustainable exploitation of both species of crabs and European lobster, both in the context of OWFs and also the Dutch Continental Shell. Insight and knowledge should be generated on the in-seasonal renewal of the local populations after catchment (by in-seasonal migration): after how many harvests can a license holder return? Also the population renewal over the years is of major importance for the exploitability of OWFs for passive fisheries. On a larger scale much interest is focused on crab fisheries lately, also from the UK and Ireland. Concerns are expressed on the sustainability of these exploitations. Momentarily there are no stock assessments on brown crab and velvet swimming crab nor is there any policy nor harvest constraints. At the moment fishery entrepreneurs start to invest in new or adapted ships. Is that wise? A first DCP stock assessment should shed light on the overall potential of brown crab and velvet swimming crab stocks to underpin the investments (or advice contrarily). 


\section{Quality Assurance}

Wageningen Marine Research utilises an ISO 9001:2015 certified quality management system. The organisation has been certified since 27 February 2001. The certification was issued by DNV. 


\section{References}

Bennett D. B., 1974. The effects of pot immersion time on catches of crabs, Cancer pagurus L. and lobsters, Homarus gammarus (L.), ICES Journal of Marine Science, Volume 35, Issue 3, Pages 332-336, https://doi-org.ezproxy.library.wur.nl/10.1093/icesjms/35.3.332

CEFAS 2020. Edible crab (Cancer pagurus): Cefas Stock Status Report 2019. Centre for Environment Fisheries \& Aquaculture Science Suffolk, UK.

Coleman M., Rodrigues E., (2017). Orkney Brown Crab (Cancer pagurus) Tagging Project. Orkney Shellfish Research Project. Orkney Sustainable Fisheries Ltd. No.19, Pp 21.

Davies, C. E., Johnson, A. F., Wootton, E. C., Greenwood, S. J., Clark, K. F., Vogan, C. L., and Rowley, A. F. 2015. Effects of population density and body size on disease ecology of the European lobster in a temperate marine conservation zone. ICES Journal of Marine Science, 72: 128-138

Didderen, K., W. Lengkeek, J.W.P. Coolen \& H.W. Waardenburg, 2013. Harde substraten en biodiversiteit. Vooronderzoek naar kunstmatige objecten in de Noordzee (NCP). Rapport 12-181. Bureau Waardenburg, Culemborg.

Hunter E, Eaton D, Stewart C, Lawler A, Smith MT (2013) Edible Crabs "Go West": Migrations and Incubation Cycle of Cancer pagurus Revealed by Electronic Tags. PLOS ONE 8(5): e63991. https://doi.org/10.1371/journal.pone.0063991

Lovewell S. R., A. E. Howard, D. B. Bennett, The effectiveness of parlour pots for catching lobsters (Homarus gammarus (L.)) and crabs (Cancer pagurus L.), ICES Journal of Marine Science 44, Issue 3, 1988, Pages 247-252, https://doi-org.ezproxy.library.wur.nl/10.1093/icesjms/44.3.247

Miller, R. J. (1979). "Saturation of crab traps: Reduced entry and escapement." Journal du Conseil 38(3): 338-345.

Miller, R. J. (1990). "Effectiveness of crab and lobster traps." Canadian Journal of Fisheries and Aquatic Sciences 47(6): 12281251.

Ministerie van Economische Zaken, Landbouw en Innovatie (2021). Uitvoeringsregeling zeevisserij. Geldend van 01-08-2021 t/m heden. wetten.nl - Regeling - Uitvoeringsregeling zeevisserij BWBR0030288 (overheid.nl)

Moland E, Moland Olsen E, Knutsen H, Knutsen JA, Enersen SE, André C, Stenseth NC (2011) Activity patterns of wild European lobster Homarus gammarus in coastal marine reserves: implications for future reserve design. Mar Ecol Prog Ser 429:197-207. https://doi.org/10.3354/meps09102.

Montgomery, S. S. (2005). "Effects of trap shape, bait, and soak time on sampling the eastern rock lobster, Jasus verreauxi." New Zealand Journal of Marine and Freshwater Research 39(2): 353363.

Öndes, F., Emmerson, J., Kaiser, M., Murray, L., \& Kennington, K. (2019). The catch characteristics and population structure of the brown crab (Cancer pagurus) fishery in the Isle of Man, Irish Sea. Journal of the Marine Biological Association of the United Kingdom, 99(1), 119-133. doi: $10.1017 /$ S0025315417001849

Reidenbach, M. A. and M. A. R. Koehl (2011). "The spatial and temporal patterns of odors sampled by lobsters and crabs in a turbulent plume." The Journal of Experimental Biology 214(18): 3138-3153.

Roach Mike, Mike Cohen 2020. Westermost Rough Offshore Wind Farm Shellfish Survey 2017. A study commissioned by the Holderness Fishing Industry Group. DOI: 10.13140/RG.2.2.15450.57289

Roach, Michael. (2019). Interaction between the Yorkshire coast static gear fishery and offshore wind energy development Biological \& Marine Sciences UofH. University of Hull Thesis for: PhD. DOI: 10.13140/RG.2.2.20483.73766

Rozemeijer M.J.C, R. Cramer, A. Korving, C. Meeldijk (2021). Het testen van aangepaste Bruce ankers op hun geschiktheid voor het gebruik in Offshore Windmolenparken. Wageningen Marine Research Briefrapportage KD-2021-018_Alternatieve ankers in windparken op zee BO-43-119.01-012XXX. 2134054.MR.mb.

Rozemeijer M.J.C., A. Korving, J. Don, W. Zaalmink (2020) Work Method Statement Project Win-Wind to catch brown crab and lobster in Princess Amalia Offshore Wind Park. Wageningen Marine Research report C028/20, CONFIDENTIAL. 
Rozemeijer M.J.C. Korving A., R. Cramer, (2022a). String mobilisatie onder verschillende condities. Aanvullende bijlage voor Work Method Statement van TKI project Win-Wind met maatgevende weerscondities. Wageningen Marine Research Briefrapportage in prep.

Rozemeijer M.J.C, R. Cramer, A. Korving, C. Meeldijk (2022b). The damage inflicted by Bruce anchors to an infield electricity cable of Prinses Amalia Wind Park. Wageningen Marine Research letter report in prep.

Rozemeijer M.J.C, R. Cramer, B. Deetman, A. Korving (2022c) An overview and conclusion concerning the use of Bruce anchors to anchor crab-pot-strings in Prinses Amalia Offshore Windpark. Wageningen Marine Research letter report in prep.

Skerritt, Daniel, Bannister, Robert, Polunin, Nicholas, Fitzsimmons, Clare. (2020). Inter- and intraspecific interactions affecting crustacean trap fisheries-Implications for management. Fisheries Management and Ecology. 27. 10.1111/fme.12425.

Smaal A., Kamermans P., Kleissen F., van Duren L., van der Have T. (2017). Opportunities for the development of flat oyster populations on existing and planned wind farms in the Dutch section of the North Sea Wageningen Marine Research rapport C052/17. 52 blz.

Smith IP, Jensen AC, Collins KJ, Mattey EL (2001) Movement of wild European lobsters Homarus gammarus in natural habitat. Mar Ecol Prog Ser 222:177-186.

Stelzenmüller, V., A. Gimpel, H. Haslob, J. Letschert, J. Berkenhagen \& S. Brüning (2021) Sustainable co-location solutions for offshore wind farms and fisheries need to account for socio-ecological trade-offs. Science of The Total Environment, 776, 145918.

Sundberg, Per. (1985). A model for the relationship between catch and soak time in baited fish traps. Océanogr. trop. 20 (1): 19-24 (1984).

Tonk, L. and Rozemeijer, M.J.C. 2019. Ecology of the brown crab (Cancer pagurus) and production potential for passive fisheries in Dutch offshore wind farms. Wageningen, Wageningen Marine Research (University \& Research centre), Wageningen Marine Research report number C064/19.

Tonk, L. and Rozemeijer, M.J.C. 2022. Passive low impact fisheries of brown crab (Cancer pagurus) and European lobster (Homarus gammarus) in Dutch offshore wind farms Wageningen Marine Research report 2022 in prep.

Tully Oliver, Martin Robinson, Eimear O'Keefe, Ronan Cosgrove, Owen Doyle and Bridget Lehane, 2006. The Brown Crab (Cancer pagurus L.) Fishery: Analysis of the resource in 2004 - 2005. Fisheries Resource Series, Bord Iascaigh Mhara (Irish Sea Fisheries Board), Dun Laoghaire, Ireland Vol. 4, 2006, 48pp.

Ungfors A, Hallbäck H, Nilsson PG (2007) Movement of adult edible crab (Cancer pagurus L.) at the Swedish West Coast by mark-recapture and acoustic tracking. Fish Res 84: 345-357.

van den Bogaart L., Poelman M., Neitzel S., Tonk L., van der Wal J.T., Coolen J., Machiels M., met bijdrage van MJC Rozemeijer, I. de Boois, S. Vergouwen, L. van Duren (2019). Geschiktheid zeewindparken voor maricultuur en passieve visserij. Een kwalitatieve beoordeling van geschiktheid van windparklocaties voor voedselproductie. Wageningen Marine Research Report C044/19, BO-43-023.03-005

Van Stralen, M. R. en E. W. M. Smeur (2008) Effecten van sleepnetvisserij en visserij met vaste vistuigen op vogels, zeezoogdieren, migrerende vissoorten en kreeften. Deelstudie Kreeft. Bureau MarinX, Rapport nummer: 2008.49, 51 pagina's.

Wallace Natalie, Rae Vicky (2018). Escape Gap Project 2016-17. Northumberland Inshore Fisheries and Conservation Authority report.

Woll A.K., Gro I. van der Meeren, Inge Fossen, Spatial variation in abundance and catch composition of Cancer pagurus in Norwegian waters: biological reasoning and implications for assessment. ICES Journal of Marine Science, Volume 63, Issue 3, 2006, Pages 421-433, https://doiorg.ezproxy.library.wur.nl/10.1016/j.icesjms.2005.10.004 


\section{Justification}

Report C107/21

Project Number: 4316100277

The scientific quality of this report has been peer reviewed by a colleague scientist and a member of the Management Team of Wageningen Marine Research

Approved: $\quad$ Linda Tonk

Researcher

Signature:

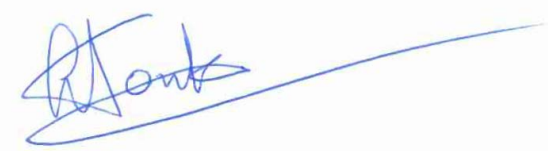

Date: 10-01-2022

Approved: Jakob Asjes

Manager Integration Wageningen Marine Research

Signature:

Date:

10-01-2022 


\section{Annex 1 Figures}

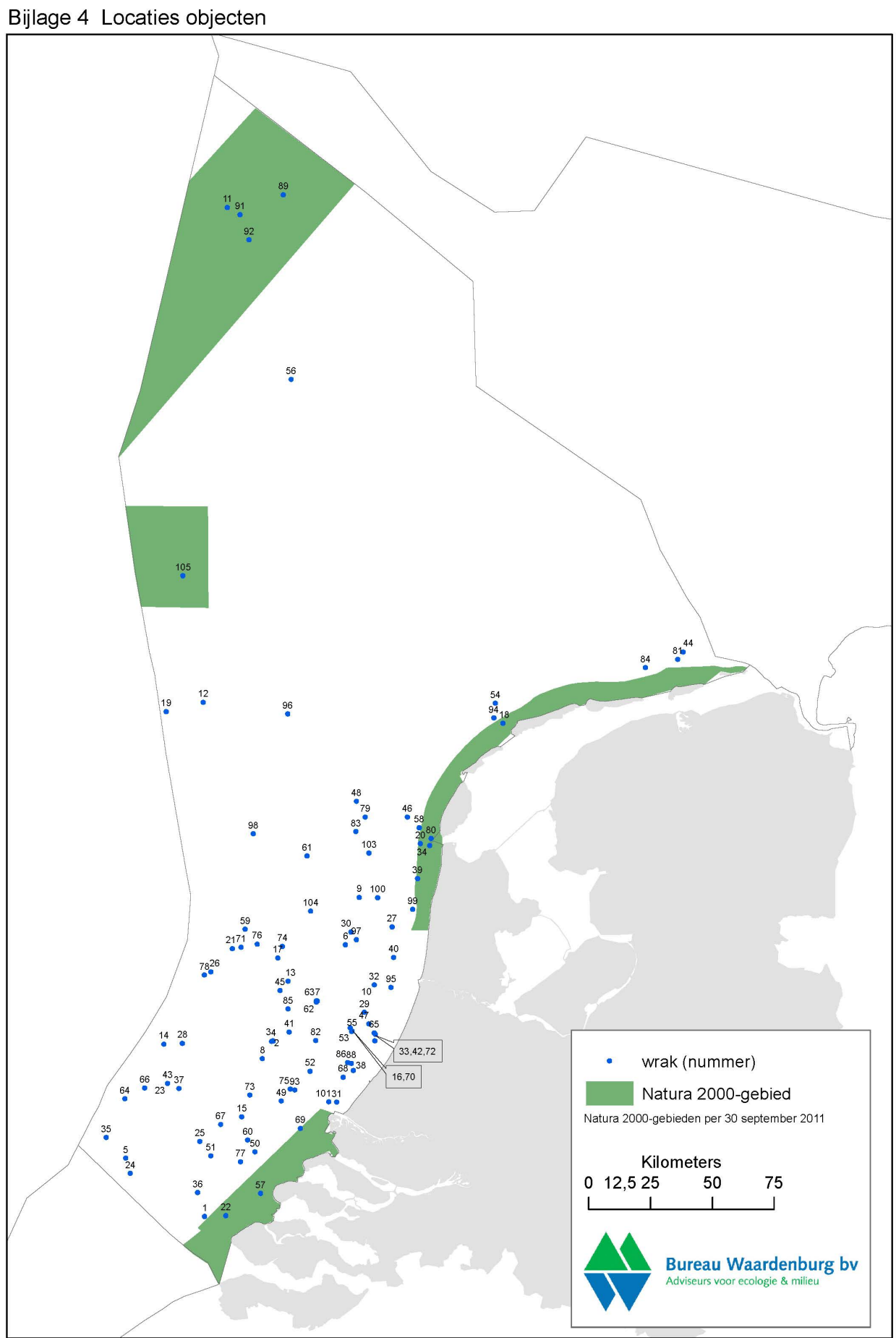

Figure 10 Locations of the wrecks: 38: Hr MS Adder; 86: Houtrust; 88: Key West. (fig. from Didderen et al., 2013). 


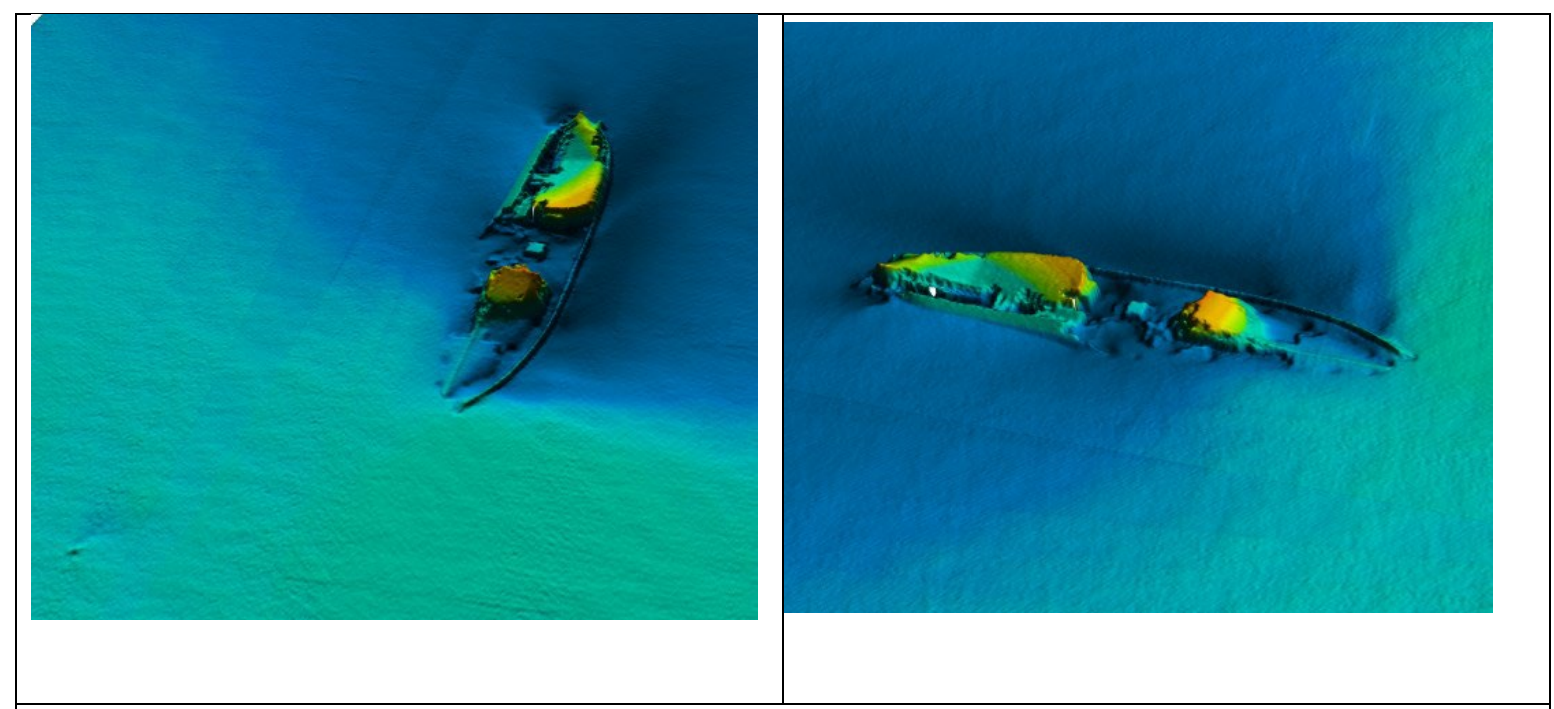

Figure 11 Multibeam Echosounder of the Adder (EM2040c, 17-08-2020, courtesy Janneke Bos Rijkswaterstaat).

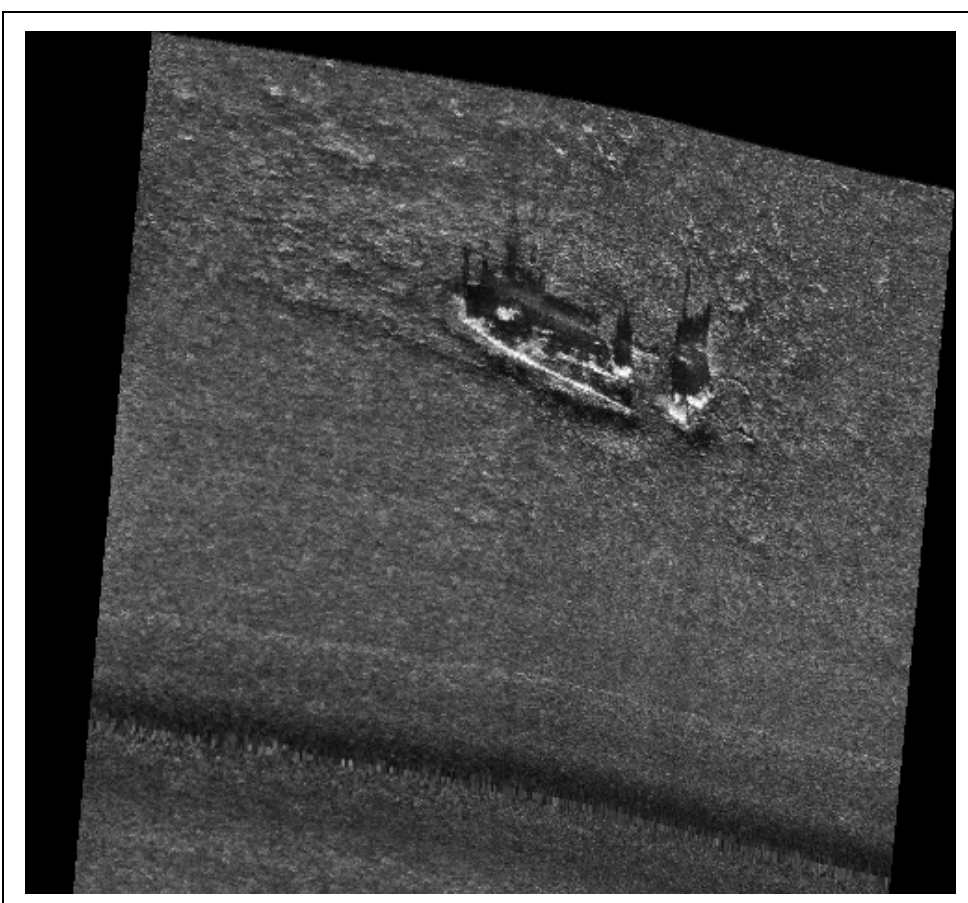

Figure 12 Sonar images of the Houtrust (made in 2011), with courtesy of Arno Meurink, head department of data management, Department of Hydrography, Royal Navy, Ministry of Defense. 


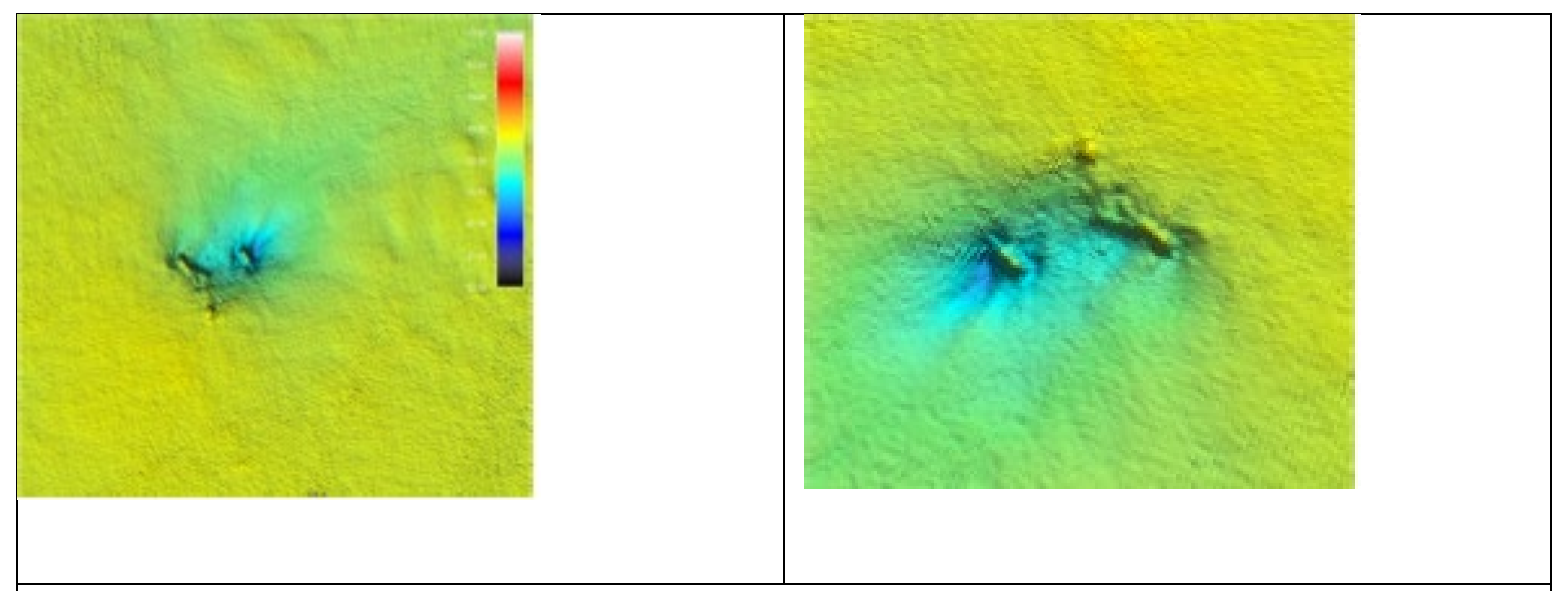

Figure 13 Multibeam Echosounder of the Key West (EM2040c, 17-08-2020, courtesy Janneke Bos Rijkswaterstaat). 
Wageningen Marine Research

$\mathrm{T}+31$ (0)31748 7000

E: marine-research@wur.nl

www.wur.eu/marine-research

Visitors' address

- $\quad$ Ankerpark 271781 AG Den Helder

- $\quad K o r r i n g a w e g ~ 7,4401$ NT Yerseke

- Haringkade 1, 1976 CP IJmuiden
With knowledge, independent scientific research and advice, Wageningen Marine Research substantially contributes to more sustainable and more careful management, use and protection of natural riches in marine, coastal and freshwater areas.
Wageningen Marine Research is part of Wageningen University \& Research. Wageningen University \& Research is the collaboration between Wageningen University and the Wageningen Research Foundation and its mission is: 'To explore the potential for improving the quality of life' 